$\begin{array}{lllllllllllllllll}C & \mathbf{O} & \mathbf{N} & \mathbf{C} & \mathbf{O} & \mathbf{R} & \mathbf{D} & \text { I } & \text { A } & \text { D } & \text { I } & \text { S } & \text { C } & \mathbf{O} & \mathbf{R} & \mathbf{S}\end{array}$

\title{
№4(23)
}

2014

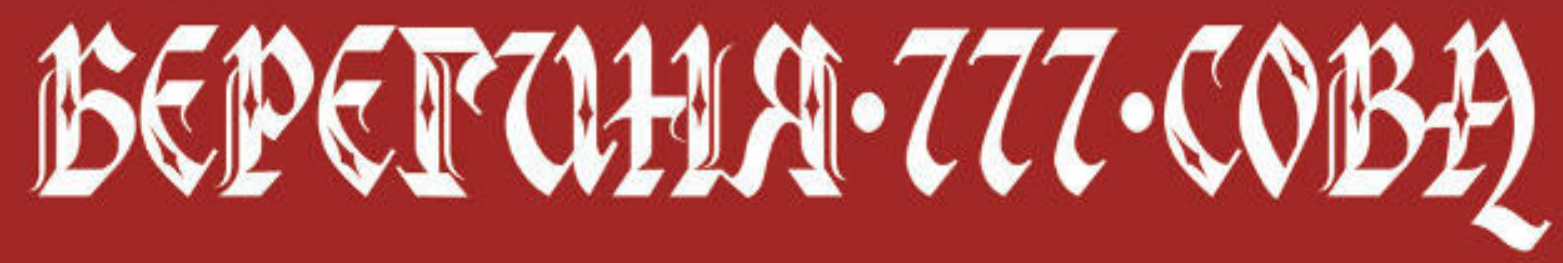

ISSN 2077-6365
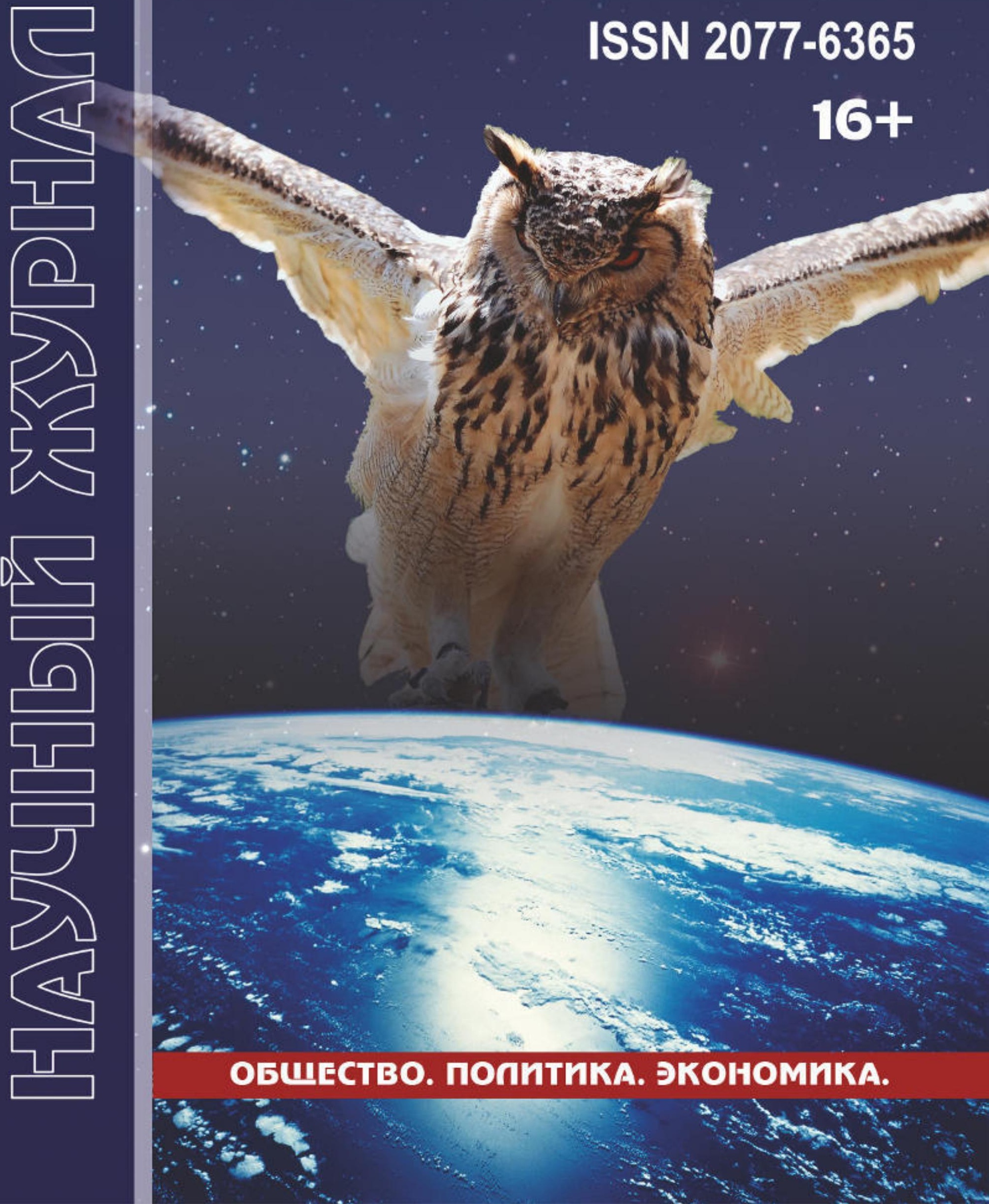


\section{Concordia Discors}

ISSN 2077-6365

(16)

\section{БЕРЕГИНЯ - 777 - СОВА,}

\section{4, № 4 (23)}

Научный журнал 
Берегиня • 777 • Сова. Научный журнал / Гл. редактор: профессор Р.Г. Гостев, зам. гл. ред. профессор Е.П. Белозерцев, профессор Г.К. Сафаралиев. - М.: Еврошкола, Воронеж: ОАО «Воронежская областная типография», 2014, № 4 (23): Фашизм и правый радикализм в Европе и Америке: история и современность (часть I) / Отв. ред.: А.А. Галкин, А.А. Богдашкин; зам. отв. ред.: Л.С. Окунева. - 397 с.

\section{ISSN 2077-6365}

ISBN 978-5-87456-862-7

Благодарим сотрудников Управления библиотечных фондов (Парламентской библиотеки) за информаџионно-библиографическую помощь в подготовке статей к печати.

В журнале «Берегиня•777•Сова», 2014, № 4 (23) опубликованы статьи под рубриками: «Концептуальные представления о фашизме и правом радикализме», «Итальянский фатизм и германский националсоииализм», «Фашизм и диктаторские режимы в Иберийских странах», «Фатизм и правый радикализм в Австрии, Франции и странах Бенилюкса», «Фашизм и правый радикализм в странах Северной Европыз».

Статьи рецензируются. Не рецензируются статьи чл.-кор., академиков РАН, РАО, руководителей политических партий, представленных в Государственной Думе Федерального Собрания Российской Федерации, членов редакиионного совета. Мнение авторов может не совпадать с позициями редакционного совета.

Статьи аспирантов печатаются бесплатно.

ISSN 2077-6365

ISBN 978-5-87456-862-7

(C) Берегиня $\bullet 777 \bullet$ Сова, 2014

(C) Авторы, 2014

(C) Оформление обложки С.В. Вашурин 


\section{Берегиня • 777 • Сова, 2014, № 4 (23)}

Издается с 2009 года

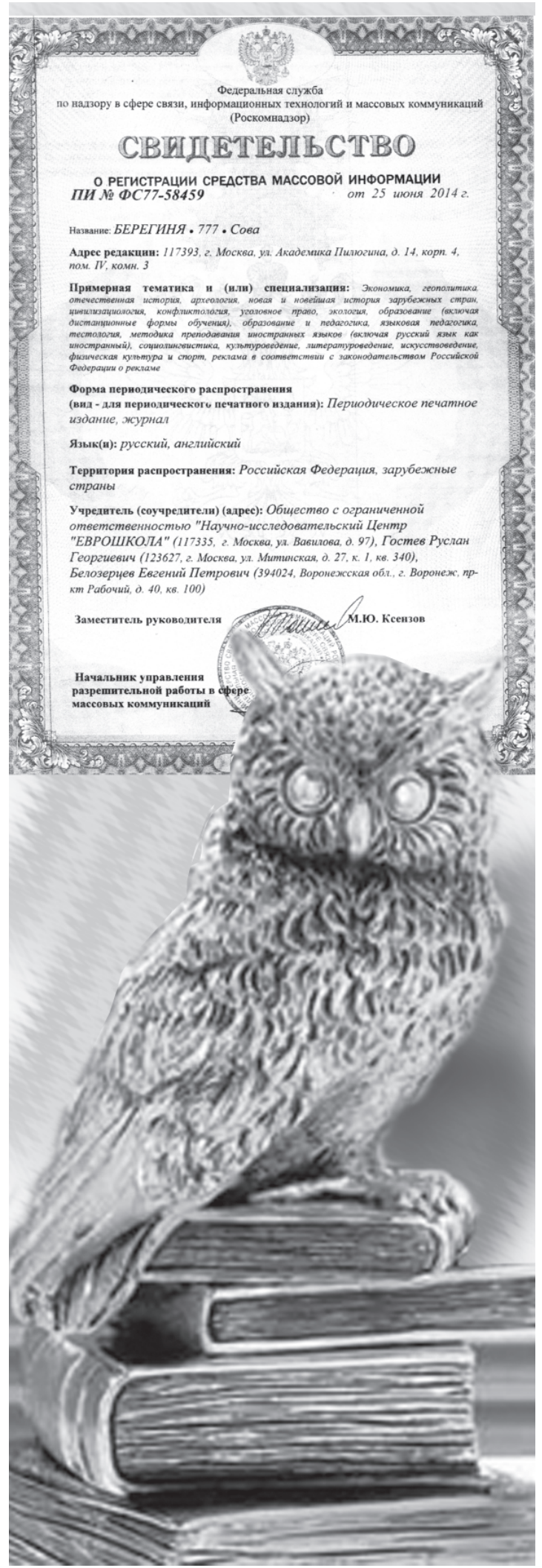

РЕДАКЦИОННЫЙ СОВЕТ:

P.Г. Гостев, доктор исторических наук, профессор, депутат Государственной Думьл Федерального Собрания Российской Федерации главный редактор (г. Москва)

E.П. Белозериев, доктор педагогических наук, профессор, заслуженный деятель науки РФ - заместитель главного редактора (2. Воронеж)

Г.К. Сафаралиев, член-корреспондент РАН, Председатель комитета Государственной Думь по делам начиональностей-заместитель главного редактора (г. Москва)

\section{ЧЛЕНЫ РЕДАКЦИОННОГО СОВЕТА:}

С.В. Алексеев, доктор юридических наук, профессор (2. Москва) С.Н. Бабурин, доктор юридических наук, профессор (2. Москва)

Г.А. Балыхин, доктор экономических наук, профессор, член-корреспондент РАО, депутат Государственной Думы Федерального Собрания Российской Федераџии (г. Москва) А.В. Белоусов, доктор экономических наук, профессор (2. Воронеж) М.Н. Берулава, доктор педагогических наук, профессор, академик РАО, депутат, заместитель Председателя Комитета Государственной Думы по образованию (2. Москва)

И.М. Братищев, доктор экономических наук, профессор, академик PAEH (2. Москва)

Жан Брио, профессор (Франиия)

В.В. Варава, доктор философских наук, профессор (2. Воронеж)

A.В. Глухова, доктор политических наук, профессор (2. Воронеж) A.A. Горелов, доктор педагогических наук, профессор

(2. Санкт-Петербург)

В.И. Гусева, доктор экономических наук, профессор (Кыргызстан) А.-Н.3. Дибиров, доктор политических наук, профессор (2. Махачкала)

Л.Н. Доброхотов, доктор философских наук, профессор (2. Москва) Н.А. Душкова, доктор исторических наук, профессор (2. Воронеж) В.С. Каменков, доктор юридических наук, профессор

(2. Минск, Беларусь)

Владимир Крилян, профессор (Сербия)

Д.В. Ливенцев, доктор исторических наук, профессор (2. Воронеж)

В.И. Лисов, доктор экономических наук, профессор, член-

корреспондент РАO (2. Москва)

В.Н. Лихачев, доктор юридических наук, профессор, депутат Государственной Думы Федерального Собрания Российской Федераиии

А.В. Лотоненко, доктор педагогических наук, профессор (2. Воронеж)

М.М. Любимов, доктор технических наук, профессор (2. Москва) A.A. Лютых, доктор исторических наук, профессор (2. Чикаго, США)

В.И. Мунтиян, доктор экономических наук, профессор, член-корреспондент Национальной академии Украины (2. Киев) Д.Н. Нечаев, доктор политических наук, дочент (2. Воронеж) С.П. Обухов, доктор политических наук, депутат Государственной Думы Федерального Собрания Российской Федерачии Д.С. Папазов, профессор (Болгария)

А.В. Перепелицын, доктор исторических наук, профессор (2. Воронеж)

Джованни Перрино, профессор (Италия)

В.П. Пешков, доктор соииологических наук, депутат Государственной Думь Федерального Собрания

Российской Федераиии

Г.Г. Провадкин, доктор исторических наук, профессор (2. Москва) Т.Х. Рыскалиев, доктор философских наук, профессор (Казахстан) А.Ф. Сафонов, доктор исторических наук, профессор (2. Москва)

А.А. Слезин, доктор исторических наук, профессор (2. Тамбов) С.И. Филимонова, доктор педагогических наук, профессор (2. Москва)

В.Н. Фурсов, доктор исторических наук, профессор (2. Воронеж) C.P. Гостева, кандидат исторических наук, дочент, ответственный секретарь (2. Воронеж)

УЧРЕДИТЕЛИ: ООО „Научно-исследовательский Центр «ЕВРОШКОЛА», Р.Г. Гостев, Е.П. Белозериев 


\section{ФАШИЗМ И ПРАВЫЙ РАДНКАЛИЗМ B EBPOIE H AMEPHKE: ИCTOPHЯ И COBPEMEHHOCTb}

\section{(4ACTb I)}

Общее руководство проектом осуществил:

Гостев Руслан Георгиевич - доктор исторических наук, профессор

(Москва, Россия)

\section{РЕДАКЦИОННАЯ КОЛЛЕГИЯ}

Ответственные редакторы:

Галкин Александр Абрамович - доктор исторических наук, профессор, академик РАЕН (Москва, Россия)

Богдашкин Александр Андреевич - кандидат исторических наук (Воронеж, Россия)

Заместитель отв. ред.:

Окунева Людмила Семеновна - доктор исторических наук, профессор (Москва, Россия)

Oтв. секретари:

Строганова Елена Дмитриевна - кандидат исторических наук (Москва, Россия)

Рори Йомэнс - доктор истории (София, Болгария)

\section{Члены редакционной коллегии:}

Величко Ольга Ивановна - доктор исторических наук, академик РАЕН (Москва, Россия)

Носкова Альбина Федоровна - доктор исторических наук

(Москва, Россия)

Кевин Пэссмор - доктор, профессор истории

(Кардифф, Великобритания)

Дон Ваттс - доктор истории (Сторе Хеддинг, Дания)

Лючия Чечи - доктор истории, ассистент профессора современной истории (Рим, Италия) 


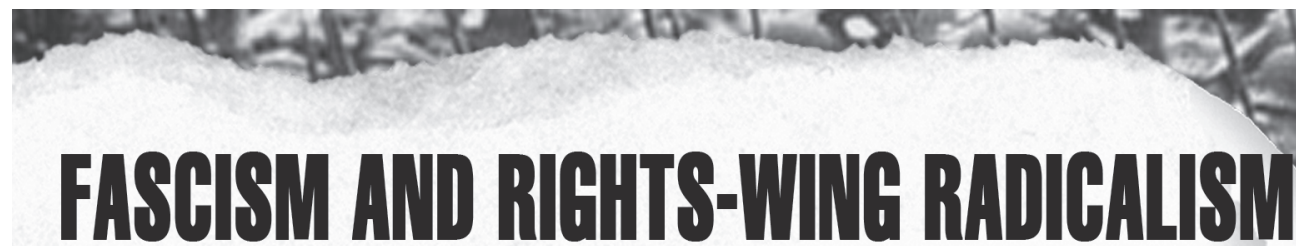 IN EUROPE AND AMERRCA: \\ PAST AND PRESENT}

\section{(PART I)}

The general management of this project:

Ruslan Gostev, Doctor of Historical Sciences, Professor

(Moscow, Russia)

\section{EDITORIAL BOARD:}

Editors-in-Chief:

Alexander Galkin, Doctor of Historical Sciences, Professor (Moscow, Russia)

Alexander Bogdashkin, Candidate of Historical Sciences

(Voronezh, Russia)

\section{Senior Editor:}

Liudmila Okuneva, Doctor of Historical Sciences, Professor

(Moscow, Russia)

Executive Secretaries:

Elena Stroganova, Candidate of Historical Sciences

(Moscow, Russia)

Rory Yeomans, Doctor of History

(Sofia, Bulgaria)

Member of Editorial Board:

Olga Velichko, Doctor of Historical Sciences (Moscow, Russia)

Albina Noskova, Doctor of Historical Sciences (Moscow, Russia)

Kevin Passmore, Professor of History

(Cardiff, the United Kingdom)

Don Watts, Doctor of History

(Store Heddinge, Denmark)

Lucia Ceci, Doctor of History, Assistant Professor (Rome, Italy) 
Введение

\section{КОНЦЕПТУАЛЬНЫЕ ПРЕДСТАВЛЕНИЯ О ФАШИЗМЕ И ПРАВОМ РАДИКАЛИЗМЕ}

Галкин А.А. (Россия) Фашизм как общественный недуг ..................................................... 11 Джефф Эли (США) Теории фашизма: проблема интерпретации .....................................222 Богдашкин A.A. (Россия) Советская и постсоветская историография о причинах установления фашистских диктатур в странах Западной Европы .................................................. 41

Антониу Кошта Пинту (Португалия) Фашизм, корпоративизм и создание авторитарных институтов в диктаторских государствах Европы в межвоенный период .... .70

Кас Мудде (США) Популистские праворадикальные партии в современной Европе .............. 91

Клаус фон Байме (Германия) Популизм и правый экстремизм в партийных системах эпохи постмодерна. 101

\section{ИТАЛЬЯНСКИЙ ФАШИЗМ И ГЕРМАНСКИЙ НАЦИОНАЛ-СОЦИАЛИЗМ}

Яхимович 3.П. (Россия) Происхождение итальянского фашизма и его путь к власти . 110 Джулия Альбанезе (Италия) Поход на Рим и завоевание власти фашистами .... 119 Лючия Чечи (Италия) “Это движение стало необходимостью": католическая церковь и фашистское насилие в Италии (1920-1924 гг.) ...... 127 Симоне Дуранти (Италия) Система образования и пропаганда в фашистской Италии ........... 140 Франклин Хью Адлер (США) “Евреи - сначала буржуа, затем враги, а потом жертвы”: поворот итальянского фашизма к расизму в 1938 году ... 150 Коломиец В.К. (Россия) Фашизм в исторической памяти современности: итальянский вариант .............................................. 164 Эндрю Дж. Боннел (Австралия) Германские элиты и захват власти нацистами в 1933 г .. 173 Хавкин Б.Л. (Россия) Германский националсоциализм .......................................... 183 Армин Нольцен (Германия) НСДАП и немецкая “народная общность" в 1933-1945 гг .......... 194 Бровко Л.Н. (Россия) Протестантизм и национал-социализм 208
Дашичев В.И. (Россия) Европа в завоевательных планах германского фашизма ............. 221 Лебедева Н.С. (Россия) СССР и Нюрнбергский процесс ............................................ 239 Поташинская Н.Н. (Россия) Пий XII и

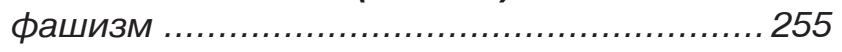

\section{ФАШИЗМ И ДИКТАТОРСКИЕ РЕЖИМЫ В ИБЕРИЙСКИХ СТРАНАХ}

Марио Ивани (Португалия) Кризис либеральной демократии в Португалии и «Новое государство» Салазара ................................................ 268

Хавьер Касалс Месегер (Испания) Век фашизма в Испании (1918-2014) ..........................2 279 Франсиско Моренте (Испания) Испанская фаланга, фашистские диктаторы и Гражданская война (1936-1939) ................................. 289

\section{ФАШИЗМ И ПРАВЫЙ РАДИКАЛИЗМ В АВСТРИИ, ФРАНЦИИ И СТРАНАХ БЕНИЛЮКСА}

Величко О.И. (Россия) Австрофашизм: между Муссолини и Гитлером ............................. 300 Кевин Пэссмор (Великобритания) Транснациональная история фашизма и национал-социализма на примере Франции ...................... 310 Майкл Б. Лафлин (США) Историография французского фашизма: «Национальный фронт» - аватар сегодняшнего дня? ............................ 328 Боб Мур (Великобритания) Фашизм в Нидерландских землях (1919-1945) ...................... 341

\section{ФАШИЗМ И ПРАВЫЙ РАДИКАЛИЗМ В СТРАНАХ СЕВЕРНОЙ ЕВРОПЫ}

Сальваторе Гарау (Великобритания) Преддверие норвежского фашизма: радикализация городского правого национализма в Норвегии между двумя мировыми войнами .................... 352

Корунова Е.В. (Россия) Современные неонацистские тенденции в общественной жизни Швеции в зеркале национал-социализма 1920-1930-х годов ............................................... 370

Килин Ю.М. (Россия) Крайне правый радикализм в Финляндии в 1920-1930-е гг............ 380

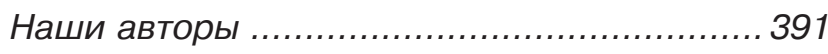




\section{CONTENTS 2014, № 4 (23)}

A.A. Galkin. FASCISM AS A SOCIAL ILL 11

Geoff Eley. WHERE ARE WE NOW WITH THEORIES OF FASCISM? 22

A.A. Bogdashkin. SOVIET AND POST-SOVIET RUSSIAN HISTORIOGRAPHY ON THE REASONS FOR THE ESTABLISHMENT OF FASCIST DICTATORSHIPS IN WESTERN EUROPE

Antonio Costa Pinto. FASCISM, CORPORATISM AND THE CRAFTING OF AUTHORITARIAN INSTITUTIONS IN INTER-WAR EUROPEAN DICTATORSHIPS.

Cas Mudde. POPULIST RADICAL-RIGHT PARTIES IN EUROPE TODAY ............................... 91

Klaus von Beyme. POPULISM AND RIGHT-WING EXTREMISM IN POSTMODERN PARTY SYSTEMS .... 101

Z.P. Yahimovich. ORIGIN OF ITALIAN FASCISM AND ITS PATH TO POWER .............................. 110

Giulia Albanese. THE MARCH ON ROME AND THE SEIZURE OF POWER BY THE FASCISTS .......... 119 Lucia Ceci. "THIS MOVEMENT HAS BECOME A NECESSITY": THE CATHOLIC CHURCH AND THE POLITICAL VIOLENCE OF FASCISM IN ITALY, 1920-1924

Simone Duranti. SCHOOLS AND FASCISM: FASCIST GROUPS IN ITALIAN UNIVERSITIES AND THEIR PROPAGANDA ....

Franklin H. Adler. JEW AS BOURGEOIS, JEW AS ENEMY, JEW AS VICTIM OF FASCISM: ITALIAN FASCISM'S TURN TOWARD RACISM IN 1938

V.K. Kolomiez. FASCISM IN THE HISTORICAL MEMORY OF THE CONTEMPORARY EPOCH........... 164

Andrew G. Bonnell. THE GERMAN ELITES AND THE NAZI TAKEOVER OF POWER IN $1933 \ldots \ldots \ldots \ldots . . . .173$

B.L. Khavkin. GERMAN NATIONAL SOCIALISM ........................................................ 183

Armin Nolzen. THE NSDAP AND THE GERMAN "PEOPLE'S COMMUNITY" (1933-1945) ................. 194

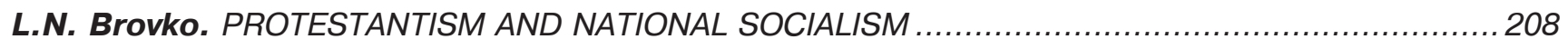

V.I. Dashichev. EUROPE IN THE AGGRESSIVE PLANS OF GERMAN FASCISM ...........................221

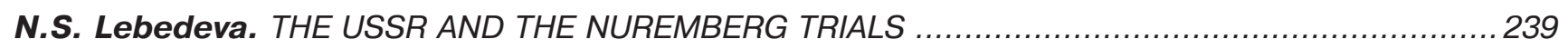

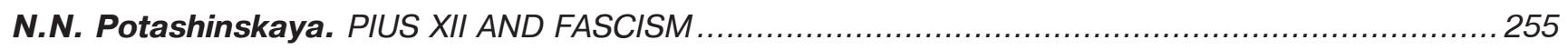

Mario Ivani. THE CRISIS OF LIBERAL DEMOCRACY IN PORTUGAL AND SALAZAR'S NEW STATE.... 268

Xavier Casals Meseguer. A CENTURY OF FASCISM IN SPAIN, 1918-2014 ..............................279

Francisco Morente. FALANGEESPAÑOLA, FASCIST DICTATORS AND THE SPANISH CIVIL WAR,

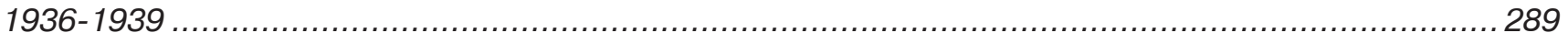

o.I. Velichko. AUSTROFASCISM: BETWEEN MUSSOLINI AND HITLER ................................... 300

Kevin Passmore. WRITING THE HISTORY OF FASCISM AND NATIONAL SOCIALISM TRANSNATIONALLY: THE EXAMPLE OF FRANCE

Michael B. Loughlin. THE HISTORIOGRAPHY OF FRENCH FASCISM: IS THE FRONT NATIONAL A CONTEMPORARY AVATAR?

Bob Moore. FASCISM IN THE LOW COUNTRIES, 1919-1945

Salvatore Garau. ANTICIPATING NORWEGIAN FASCISM: THE RADICALIZATION OF URBAN RIGHT-WING NATIONALISM IN INTER-WAR NORWAY...

E.V. Korunova. MODERN NEO-NAZI TENDENCIES IN SWEDISH PUBLIC LIFE IN THE MIRROR OF NATIONAL SOCIALISM IN THE 1920s AND 1930s. 370

Y.M. Kilin. EXTREME RIGHT-WING RADICALISM IN FINLAND IN THE 1920s AND 1930s 380 
УДК $342.39(4)$

ББК 67.99(4)

\title{
ФАШИЗМ, КОРПОРАТИВИЗМ И СОЗДАНИЕ АВТОРИТАРНЫХ ИНСТИТУТОВ В ДИКТАТОРСКИХ ГОСУДАРСТВАХ ЕВРОПЫ В МЕЖВОЕННЫЙ ПЕРИОД
}

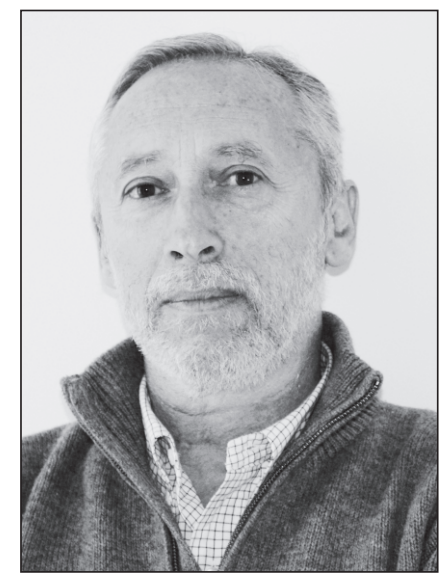

\author{
Антониу Кошта Пинту, доктор, профессор \\ политологии и современной европейской истории, \\ Институт общественных наук \\ Лиссабонского университета, \\ (Лиссабон, Португалия) \\ acpinto@ics.ul.pt
}

Перевод с английского Л.А. Каи

Аннотация. Распространение политического и социального корпоративизма, а также установление однопартийной системы являются отличительными чертами институциональных перемен в европейских диктатурах, что ставит под сомнение некоторые жесткие дихотомические интерпретации межвоенного фашизма. В данной публикации переосмысливается роль корпоративизма как политического инструмента в противовес либеральной демократии и, в частности, как набора авторитарных институтов, которые распространились по всей межвоенной Европе и стали основой гибридизации институтов фашистских диктатур. Мы утверждаем, что корпоративизм находился в авангарде этого процесса межнационального распространения общественных институтов и как новая форма представительства организованных интересов, и как авторитарная альтернатива либеральной демократии.

Ключевые слова: корпоративизм, диктатура, фашизм, законодательные органы.

\section{FASCISM, CORPORATISM AND THE CRAFTING OF AUTHORITARIAN INSTITUTIONS IN INTER-WAR EUROPEAN DICTATORSHIPS}

\author{
Antonio Costa Pinto, \\ Professor of Politics and Contemporary \\ European History, Institute of Social Sciences, \\ University of Lisbon, Portugal
}

Abstract. The diffusion of political and social corporatism, which with the single-party are hallmarks of the institutional transfers among European dictatorships, challenges some rigid dichotomous interpretations of interwar fascism. This chapter rethinks the role of corporatism as a political device against liberal democracy and especially as a set of authoritarian institutions that spread across inter-war Europe and which was an agent for the hybridization of the institutions of fascist-era dictatorships. We argue that corporatism was at the forefront of this process of cross-national diffusion, both as a new form of organized interest representation and as an authoritarian alternative to liberal democracy.

Key words: corporatism, dictatorships, fascism, legislatures.

Корпоративизм оставил неизгладимый след в истории первых десятилетий XX века, с одной стороны, как набор институтов, созданных принудительной интеграцией организованных интересов в государстве (в основном, независимых профсоюзов), а с другой, как органически-этатистская альтернатива либеральной демократии [1]. Различные варианты корпоративизма стимулировали деятель- 
ность консервативных, праворадикальных и фашистских партий, не говоря уже о Римско-католической церкви, а также воодушевляли те слои технократических элит, которые выступали за «третий путь развития». Корпоративизм также вдохновлял диктатуры (от «нового государства» Антониу ди Оливейра Салазара в Португалии, Бенито Муссолини - в Италии, Энгельберта Дольфуса - в Австрии, до государств Балтии) на создание институтов легитимации собственных режимов. Европейские варианты корпоративизма распространились по всей Латинской Америке и Азии, особенно в Бразилии, Аргентине и Турции [2].

Рассматривая диктатуры XX века, следует учитывать и определенную степень их институциональных различий. Партии, кабинеты министров, парламенты, корпоративистские объединения, хунты и целый набор параллельных и вспомогательных структур господства, мобилизации и управления были символами (часто вынужденного) разнообразия, характеризующего авторитарные режимы [3]. Эти авторитарные институты, созданные в политических лабораториях межвоенной Европы, распространились на весь мир после окончания Второй мировой войны. В частности, это касается персонализации лидерства, а также однопартийных и органически-этатистских законодательных органов. Кое-кто из современников фашизма уже тогда осознавал, что некоторые из общественных институтов, созданных межвоенными диктатурами, могут быть прочными. Как отмечал радикально ориентированный румынский ученый и авторитарный политик начала XX века Михаил Маноилеску, «из всех политических и социальных нововведений нашего века, начавшихся в 1918 году, есть два, которые определенно обогатили наследие человечества:... корпоративизм и однопартийная система» [4]. Он посвятил каждому из этих политических институтов исследование, не предполагая в 1936 году, что некоторые стороны корпоративизма окажутся долговечными, а однопартийная система станет одним из самых прочных политических инструментов диктатур [5].

Межвоенные диктатуры были персонализированными авторитарными режимами [6]. Даже те из них, которые были институциализированы в результате военных переворотов или установления военных диктатур. Они порождали персоналистские режимы и предпринимали попытки создать единые партии. Персонализация руководства диктаторских режимов стала доминирующей характеристикой фашистской эры [7]. Тем не менее, диктаторам для осуществления своей власти были необходимы институты и элиты. Между тем их роль часто недооце- нивается, как и тот факт, что принятие решений оставалось при этом прерогативой диктаторов [8].

Чтобы предотвратить подрыв легитимности власти и узурпацию полномочий, диктаторы должны были кооптировать элиты в определенные институты, которые необходимо было либо создать, либо адаптировать как место кооптации, переговоров и (иногда) принятия решений: «без институтов они не могли пойти на политические уступки» [9]. С другой стороны, как отмечает Амос Перлмуттер, ни один авторитарный режим не мог бы выжить политически без решающей поддержки таких элит, как чиновники, менеджеры, технократы и военные [10].

Если типичные фашистские режимы Италии и Германии были основаны благодаря захвату власти партией, то многие гражданские и военные правители других стран межвоенной Европы не имели «готовой организации, на которую могли положиться» [11]. Чтобы обеспечить устойчивость режима, диктаторы, как правило, создавали затем свои партии. Некоторые фашистские движения появлялись в межвоенный период либо как конкуренты, либо как временные партнеры, либо внутри правящей партии, либо (и часто) в качестве тормоза формированию правящих партий, усложняя тем самым институализацию диктаторских режимов.

Межвоенные диктатуры создавали также контролируемые парламенты, корпоративистские объединения и другие авторитарные бюрократические консультативные органы. Политические институты диктатур, даже те законодательные органы, которые некоторые авторы описывали как номинально демократические, не были просто показными: они, действительно, влияли на процесс формирования политики [12]. Автократы тоже нуждались в соблюдении требований законодательства и в сотрудничестве. В некоторых случаях диктаторам, чтобы «достичь компромисса, необходимы были номинально демократические институты». Такие институты служили форумами, в рамках которых различные фракции и даже сам режим и его оппозиция могли договариваться между собой [13]. «Номинально демократические институты могли помочь авторитарным правителям сохранять коалиции и оставаться у власти» [14], а «корпоративистские парламенты» были институтами легитимации диктатур и также местом выработки этого процесса.

В этой статье рассматривается роль системы корпоративизма как направленного против либеральной демократии политического устройства, проникшего в правые политические структуры во время первой волны демократизации, и, в частности, как набора авторитарных институтов, распространившихся по всей межвоенной Европе и ставшего 
средством гибридизации институтов диктатур фашистской эпохи. Отличительной чертой межвоенных лет были мощные процессы институциональных преобразований диктатур. И мы утверждаем, что корпоративизм оказался в авангарде этого процесса как новая форма организованного представительства интересов и как авторитарная альтернатива парламентской демократии [15].

\section{Социальный и политический корпоративизм во время первой волны демократизации}

Корпоративизм как идеология и тип организованного представительства интересов был первоначально выдвинут Римско-католической церковью в конце XIX - середине XX века в качестве противовеса социализму и либеральному капитализму [16]. Эта модель предшествовала появлению папской энциклики „Rerum Novarum ” (1891) и была связана с романтизацией средневековых европейских феодальных гильдий консерваторами XIX века, которые разочаровались в либерализме и боялись социализма и демократии. «Явное одобрение церкви уверенно переместило корпоративизм из классов семинарий в президентские дворцы», особенно после публикации еще одной энциклики - „Quadragesimo Anno" (1931) [17].

Корпоративизм стал мощным идеологическим и институциональным рычагом, используемым против либеральной демократии в первой половине XX века. Однако неокорпоративистская практика некоторых демократий во второй его половине не говоря уже о недавнем использовании этого понятия в общественных науках [18] - требует, чтобы изучаемому явлению было дано четкое определение, и чтобы в интересах концептуальной ясности социальный корпоративизм был отделен от политического.

Попытаемся сделать это.

Социальный корпоративизм «можно определить как систему представительства интересов, составные части которой образуются ограниченным числом единичных, обязательных, неконкурентных, иерархически-упорядоченных и функционально дифференцированных категорий, признанных или лицензированных (если не созданных) государством, которым предоставляется определенная репрезентативная монополия в обмен на соблюдение определенного контроля над выбором их лидеров, а также артикуляцию их требований и необходимой поддержки» [19].

Политический корпоративизм может быть определен как система политического представительства, основанная на органически-этатистском взгляде на общество, в котором его органические едини- цы (семья, местные органы власти, профессиональные ассоциации и организации, а также учреждения, представляющие определенные интересы) заменяют собой ориентированную на индивидуума электоральную модель представительства и парламентской легитимности, становясь основным и/или дополнительным законодательным или консультативным органом исполнительной власти правителя.

Определяющим идеалом теоретиков корпоративизма было органическое устройство общества в политической и экономической сферах. Он основывался на критике того, что Уго Спирито называл эгоистичным и индивидуалистским homo economicus либерального капитализма, которого должен заменить homo corporativus и который будет руководствоваться национальными интересами, общими ценностями и целями [20].

В межвоенный период корпоративизм проник в основные политические структуры консервативного и авторитарного правого политического направления: от католических партий и социального католицизма до праворадикальных роялистов" и фашистов, не говоря уже о солидаристах ${ }^{* *}$ Дюркгейма и сторонниках технократических правительств [21]. Роялисты, технократы, фашисты и социальные католики, по существу, разделяли «общие взгляды на представления о демократии и представительстве», а также на систему функционального представительства как на альтернативу либеральной демократии, предполагающую создание корпоративных избирательных округов, законодательных палат или советов, подобных тем, которые уже возникли во многих авторитарных режимах в XX веке [22]. Вместе с тем, существовали и различия между католическими корпоративистскими формулами конца XIX века и интегральными корпоративистскими установками некоторых фашистских и праворадикальных партий. Когда мы рассматриваем фашистские программы и практику правого радикализма, напри-

* Роялисты - сторонники монархической формы государственной власти. - Прим. ред.

** Солидаристы - сторонники идей солидаризма, получивших значительное распространение в конце XIX начале XX в. В идеологическом отношении они противостояли и индивидуализму, и социализму (коммунизму). В противоположность индивидуализму и либерализму солидаристы скептически относились к субъективным правам, поскольку, по их мнению, эти права разобщают членов общества, придают самому обществу атомарный характер. В отличие от социалистов, призывавших к уничтожению буржуазии и освобождению пролетариата, солидаристы считали эти классы взаимосвязанными и равно необходимыми для общественного производства. Прим. ред. 
мер, партийные движения, вдохновленные Аксьон франсез, картина становится еще яснее. Для иллюстрации приведем два примера.

Первый.

В испанской Второй республике путем объединения в 1933 году ряда консервативных католических групп была образована Испанская конфедерации автономных правых (СЕДА). Это была первая партия, основанная в результате «политической мобилизации массового католицизма». По причинам избирательного характера она не стала ярко выраженной политической партией. Тем не менее, ее влияние было заметным. Она и призывала к созданию «корпоративистской, католической и консервативной республики», похожей на те, которые создали Салазар в соседней Португалии и Дольфус в Австрии [23].

Когда Хосе Антонио Примо де Ривера вскоре основал Испанскую фалангу, он тут же предложил заменить парламент на систему корпоративистского представительства, которая бы признала семью, муниципалитеты, профсоюзы и бизнес-организации «в качестве подлинных основ государства» [24]. При этом, стремясь подчеркнуть отличие своей политической программы от установок СЕДА, он расширил ее радикальное звучание, включив в нее и национализацию банков. Содержалась в ней и критика некоторых консервативных сторон теории корпоративного государства [25].

Второй.

В Бельгии в межвоенный период католические союзы считали авторитарные модели португальского «нового государства» «этатистскими» и, следовательно, не заслуживающими копирования (избегалось даже использование слова «этатистский»). Вместе с тем, в католическом лагере существовало правое крыло, склонное позитивно оценивать практику Салазара [26]. Его представители рассматривали корпоративизм как «основу политического представительства и средство организации рабочего класса, полностью потерявшего свою независимость» [27]. «Корпоративизм ... был важным аспектом политики, хотя лишь немногие католики хотели менять демократию на корпоративистский и авторитарный режим» [28].

В католической субкультуре Бельгии существовали заметные различия между фламандцами и валлонами. При всем этом, несмотря на различия, корпоративизм пронизывал политическую культуру обеих консервативных элит, особенно, католических. Однако их влияние на институциональные реформы оставалось ограниченным. В 1938 г. сенат одобрил умеренный проект, который был скорее проектом социального согласия, чем создания корпоративисткой организации.
В ноябре 1935 г. в результате раскола Католического движения в Бельгии была образована Рексистская партия во главе с Леоном Дегрелем. Путь рексистов Дегреля к фашизму был сложным. Своими корнями это движение уходило в католический лагерь. Однако, встав на путь авторитарной радикализации, они сделали ставку на корпоративизм, отгородив себя тем самым от консерваторов [29]. Затем, усилившаяся критика парламентаризма внутри этого движения вывела его за рамки корпоративизма, который так и не стал центральной темой политической повестки дня рексистов.

Вернемся, однако, к вопросу о соотношении социального и политического корпоративизма. Будучи элементами одной и той же идеологической конструкции, они не всегда шли одинаковыми путями. Исторический опыт корпоративизма не ограничивается диктатурами. В либерально-демократических системах «имплицитные тенденции по направлению к корпоративистским структурам развивались как до появления фашизма, так и одновременно с его возникновением» [30].

Система профессионального представительства вводилась не только в диктаторских режимах. Некоторые демократии использовали этот принцип как дополнение, наряду с обычным парламентским представительством. Корпоративистская идеология была особенно присуща конституции Ирландии 1937 г. Некоторые другие демократические режимы, существовавшие в тот период и имевшие двухпалатный парламент, стали использовать систему корпоративистского представительства при формировании верхних палат [31].

Многие идеологи социального корпоративизма, особенно в католических кругах, поддерживали его идеи, но без участия в этой системе вездесущего государства. Однако на практике корпоративистские формы представительства насаждались гражданскому обществу, в основном, авторитарными политическими элитами [32]. В диктатурах межвоенной эпохи корпоративизм стал синонимом насильственного объединения организованных интересов под жестким контролем государства в единые блоки работодателей и наемных работников. Особенно это относится к профсоюзам. Социальный корпоративизм предоставил автократам формализованную систему представительства интересов, служившую управлению трудовыми отношениями и легитимизирующую подавление свободного профсоюзного движения путем кооптации некоторых его сегментов в контролируемые государством профсоюзы, часто с обязательным членством. Не в последнюю очередь корпоративистские механизмы также «позволяли государству, трудящимся и бизнесу выражать свои 
интересы и достигать тех результатов, которые, в первую очередь, удовлетворяли бы сам режим» [33].

В этот период корпоративизм использовался для обозначения не только отношений между государством и социальными группами, но также (а в некоторых случаях, и главным образом) для комплексной организации политического общества. Корпоративизм должен был заменить либеральную демократию антииндивидуалистической системой представительства [34]. Действительно, во многих случаях корпоративистские, или экономические, парламенты либо сосуществовали с обычными парламентами и помогали им, либо заменяли их новым законодательным органом с совещательными функциями, который оказывал техническую помощь правительству.

Влиятельный теоретик „Quadragesimo Anno” иезуит Генрих Пеш называл экономический парламент «ведущим клиринговым центром» своей органической теории, но его структуру должно было определить только будущее [35]. Благодаря „Rerum Novarum ", корпоративизм стал более понятным явлением. Корпоративистская реорганизация общества ассоциировалась с сильными антисветскими принципами парламентской демократии, которые проводил в жизнь Папа Пий XII. В 1937 г. Карл Левенштейн определил ее как «романтическую концепцию органического представительства» новых законодательных органов, пытавшихся стать «истинным зеркалом социальных сил нации и точной копией ее экономической структуры» [36]. Однако в диктаторских режимах корпоративистские органы играли, конечно, менее романтическую роль.

Жорж Валуа - идеолог-синдикалист «Аксьон франсез» и основатель одного из первых французских фашистских движений, кратко сформулировал функции корпоративистских законодательных органов, предложив заменить парламент Генеральными штатами. «Этот орган не должен быть собранием, на котором решения принимались бы большинством голосов или где большинство сможет сокрушить меньшинство. Скорее, это должно быть собрание, на котором корпорации скорректировали бы свои интересы в пользу национальных интересов» [37].

В 1926 г. испанский генерал Мигель Примо де Ривера вводил корпоративистские принципы в свой диктаторский режим, провозглашая, что «парламентская система потерпела крах, и не найдется таких безумцев, чтобы восстановить ее в Испании. Правительство и Патриотический союз (ПС) призывают строить государство, основанное на новой структуре. Первой ячейкой нации будет муниципалитет, который во главу угла поставит семью с ее старыми добродетелями и ее современной концепцией гражданства» [38].

В Австрии в 1934 г. канцлер Дольфус подтвердил слова испанского генерала, которые многие диктаторы обычно произносили про себя: «Этот парламент ... никогда не вернется и никогда не должен возвращаться» [39]. С этой точки зрения, корпоративизм был мощным средством институциональной гибридизации межвоенных диктатур, во многом превзойдя те основы, на которых он возник (см. таблицу 1) [40].

Таблица 1 - Диктатуры и корпоративизм в Европе (1918-1945)

\begin{tabular}{|l|l|l|l|l|}
\hline Страна & Режим & $\begin{array}{l}\text { Тип партийной } \\
\text { системы }\end{array}$ & $\begin{array}{l}\text { Социальный } \\
\text { корпоративизм }\end{array}$ & $\begin{array}{l}\text { Политический } \\
\text { корпоративизм }\end{array}$ \\
\hline Австрия & $\begin{array}{l}\text { Дольфуса-Шушнига } \\
(1934-1938)\end{array}$ & Однопартийная & Сильный & Сильный \\
\hline Болгария & $\begin{array}{l}\text { Диктатура Вельчева } \\
(1934) \\
\text { Королевская } \\
\text { диктатура (1935- } \\
\text { 1944) }\end{array}$ & Отсутствует & Сильный & Сильный \\
\hline Эстония & $\begin{array}{l}\text { Диктатура Пятса } \\
(1934-1940)\end{array}$ & Однопартийная & Сильный & Слабый \\
\hline Франция & $\begin{array}{l}\text { Режим Виши (1940- } \\
\text { 1944) }\end{array}$ & Отсутствует & Средний & Средний \\
\hline Греция & $\begin{array}{l}\text { Диктатура Метаксаса } \\
(1936-1941)\end{array}$ & Отсутствует & Средний & Слабый \\
\hline Венгрия & $\begin{array}{l}\text { Режим Хорти } \\
- \text { период Бетлена } \\
\text { - период Гембеша } \\
(1932-1935)\end{array}$ & $\begin{array}{l}\text { Правящая } \\
\text { Однопартийная }\end{array}$ & $\begin{array}{l}\text { Слабый } \\
\text { Сильный }\end{array}$ & $\begin{array}{l}\text { Слабый } \\
\text { Средний }\end{array}$ \\
\hline
\end{tabular}


Концептуальные представления о фашизме и правом радикализме

\begin{tabular}{|c|c|c|c|c|}
\hline Страна & Режим & $\begin{array}{l}\text { Тип партийной } \\
\text { системы }\end{array}$ & $\begin{array}{l}\text { Социальный } \\
\text { корпоративизм }\end{array}$ & $\begin{array}{l}\text { Политический } \\
\text { корпоративизм }\end{array}$ \\
\hline Италия & $\begin{array}{l}\text { Фашистская } \\
\text { диктатура (1922- } \\
1943)\end{array}$ & Однопартийная & Сильный & Сильный \\
\hline Латвия & $\begin{array}{l}\text { Диктатура Ульманиса } \\
\text { (1934-1940) }\end{array}$ & Отсутствует & Сильный & Средний \\
\hline Литва & $\begin{array}{l}\text { Диктатура Сметоны } \\
\text { (1926-1940) }\end{array}$ & Правящая & Сильный & Слабый \\
\hline Польша & $\begin{array}{l}\text { Диктатура } \\
\text { Пилсудского } \\
-(1926-1935) \\
-(1935-1940) \\
\end{array}$ & $\begin{array}{l}\text { Правящая } \\
\text { Однопартийная }\end{array}$ & $\begin{array}{l}\text { Слабый } \\
\text { Сильный }\end{array}$ & $\begin{array}{l}\text { Средний } \\
\text { Сильный }\end{array}$ \\
\hline Португалия & $\begin{array}{l}\text { Диктатура Сидониу } \\
\text { Паиша (1917-1918) } \\
\text { Диктатура Салазара } \\
\text { (1933-1974) }\end{array}$ & $\begin{array}{l}\text { Правящая } \\
\text { Однопартийная }\end{array}$ & $\begin{array}{l}\text { Слабый } \\
\text { Сильный }\end{array}$ & $\begin{array}{l}\text { Средний } \\
\text { Средний }\end{array}$ \\
\hline Румыния & $\begin{array}{l}\text { Королевская } \\
\text { диктатура (1937-40) } \\
\text { Диктатура Антонеску } \\
\text { (1940-1944) }\end{array}$ & $\begin{array}{l}\text { Однопартийная } \\
\text { Отсутствует } \\
\text { (после роспус- } \\
\text { ка Железной } \\
\text { Гвардии) }\end{array}$ & $\begin{array}{l}\text { Сильный } \\
\text { Слабый }\end{array}$ & $\begin{array}{l}\text { Сильный } \\
\text { Слабый }\end{array}$ \\
\hline Словакия & $\begin{array}{l}\text { Диктатура Тисо } \\
\text { (1940-1944) }\end{array}$ & Однопартийная & Сильный & Средний \\
\hline Испания & $\begin{array}{l}\text { Примо де Ривера } \\
\text { (1923-1931) } \\
\text { Франкизм (1939- } \\
\text { 1975) }\end{array}$ & $\begin{array}{l}\text { Правящая } \\
\text { Однопартийная }\end{array}$ & $\begin{array}{l}\text { Сильный } \\
\text { Сильный }\end{array}$ & $\begin{array}{l}\text { Средний } \\
\text { Сильный }\end{array}$ \\
\hline
\end{tabular}

Поскольку система представительства являлась основным элементом современных политических систем, авторитарные режимы стремились создать политические институты, в которых функция корпоративизма заключалась в том, чтобы придать легитимность органическому представительству и обеспечить кооптацию и контроль над отдельными сегментами элит и организованных интересов. «Разработка политики уступок требует наличия институциональной среды: должен существовать некий форум, доступ к которому можно контролировать и на котором требования могут быть высказаны так, чтобы не выглядеть актами сопротивления. На этом форуме компромиссы могут быть выработаны без излишнего контроля со стороны общественности, а конечные соглашения облечены в законную форму, и в таком виде их можно пропагандировать» [41].

Тенденция межвоенных диктатур к созданию органических законодательных органов не отделена от создания соответствующих партий, что обеспечи- вало легитимацию отмены политического плюрализма, побуждая авторитарную коалицию объединиться в единую или же просто правящую партию с персонифицированным лидерством.

Как отмечал Макс Вебер, другой имплицитной целью корпоративистской формы представительства было лишение широких слоев общества их гражданских прав [42]. В свою очередь, известный политолог Хуан Линц считает: «корпоративизм поощряет сущностную аполитичность населения и превращает все вопросы в технические решения и в проблематику администрирования» [43].

Институализированные на волне поляризации демократических преобразований межвоенные диктатуры были склонны выбирать корпоративизм и как способ репрессий, и как способ кооптации рабочего движения, групп интересов и элит через органические законодательные органы. Именно с этой точки зрения мы снова рассмотрим процессы создания институтов межвоенных европейских диктатур, в 
частности, корпоративистских социальных и политических институтов и партий этих режимов.

\section{Межвоенные диктатуры и корпоративистские институты. Примат итальянского фашизма}

В своем знаменитом футуристическом манифесте 1918 г. Филиппо Маринетти объявил о необходимости «преобразования парламента с помощью равноправного участия промышленников, фермеров, инженеров и бизнесменов в правительстве страны» [44]. Но у него были и предшественники. Последовательно отстаивали идею интегрального корпоративизма и национального синдикализма еще до своего объединения с Национальной фашистской партией (НФП) националисты Энрико Коррадини и Альфредо Рокко. Рокко, отстаивая интегральный синдикализм, представлял его и как интеграцию в государство организованных групп интересов, и как ликвидацию парламента и сената путем передачи их функций органам, формируемым на основе профессионального принципа [45]. Этатизм Рокко, пожалуй, более других отличал его от католического корпоративизма, поскольку являл собой стратегию пассивной и подчиненной интеграции масс в государство.

Многие авторы подчеркивают примат в итальянском фашизме институциональной реформы над экономическими интересами. В своей инаугурационной речи перед «Фашио ди комбаттименто» (Союзом борьбы) Муссолини настойчиво указывал на необходимость введения системы «прямого представительства интересов». Затем это положение было включено в программу НФП 1921 г. [46]. Со времен похода на Рим в 1922 г. Муссолини и НФП не переставали размышлять об институциональной реформе и, прежде всего, о ликвидации принципа либерального представительства. Однако легальный характер захвата власти и наличие монарха, наследника либеральных времен, растянули этот процесс по времени и сделали его весьма напряженным [47].

Первоначальной задачей фашистов было обеспечение политического контроля над парламентом. Добившись этого, они устранили его способность к законодательной инициативе и провозгласили независимость исполнительной власти и, прежде всего, главы правительства [48]. После этого «корпоративистские установки» постоянно присутствовали в их предложениях, предусматривавших ликвидацию парламента, которому удалось просуществовать - по крайней мере, формально - еще в течение нескольких лет. В 1929 г. прямые выборы в парламент были заменены плебисцитами, на которых итальянцы могли поставить в бюллетене отметку «да»или «нет» за весь список кандидатов, предварительно утвержденных Большим фашистским советом на основании предложений НФП, фашистских синдикатов и деловых организаций. Таким образом, представительство стало органическим и сопровождалось корпоратизацией групп интересов, как предусматривалось Хартией труда 1927 г, а также созданием палаты, в которой доминировала НФП. Как декларация принципов фашистского корпоративизма Хартия труда в полной мере не оправдывала чаяний фашистского синдикализма. Однако она стала затем самым влиятельным документом для тех иностранных диктатур, которые официально приняли социальный корпоративизм [49].

В 1931 г. Муссолини призвал Большой фашистский совет приняться за реформу парламента. Разработать ее проект было поручено секретарю НФП Джованни Джуриати, который одновременно был его президентом. Тем самым дискуссии о корпоративизме и реформе представительства был придан особо актуальный характер [50].

Существовало несколько вариантов преобразований в рамках ограниченного плюрализма. Бывший националист Рокко призывал к созданию такой модели корпоративизма, которая ограничивалась бы в основном трудовыми отношениями. Джузеппе Боттаи требовал более децентрализованной модели, не забывая о явном желании НФП доминировать в будущей парламентской палате. Фариначчи был противником предложения о преобразовании Национального совета корпораций в корпоративистскую парламентскую палату, поскольку полагал, что это ослабит НФП. Джуриати предлагал создать фашистское законодательное собрание и распустить сенат. Но Муссолини, возможно, руководствуясь стремлением избежать конфликта с королем, выступил против ликвидации верхней палаты, ограничившись его последующей «фашизацией» [51].

Спустя некоторое время группа фашистов и близких им юристов создала другую комиссию, которая изучала законодательные системы в Германии, Польше, Португалии и Австрии [52]. Только в 1936 г., спустя 14 лет после прихода к власти, Муссолини смог объявить о создании Палаты фасций и корпораций, а также о корпоративизации политического представительства. Эта палата стала функциональным представительством национального совета НФП и Национального совета корпораций. Члены Большого фашистского совета вошли в состав Палаты по должности. Изучение списка ее членов в 1939 г. позволяет выявить наличие шаткого равновесия между советниками от НФП и корпорациями. Причем последние доминировали - по крайней мере, формально. В действительности ситуация была иной, так как НФП имела своих представителей в 
корпоративистских структурах [53]. Следует также учитывать, что Муссолини назначал национальных советников своим указом, то есть последнее слово всегда оставалось за ним.

Значимость работы, проводимой Национальным советом корпораций, а затем и палатой, а также функций кооптации и переговоров, первоначально недооцененная многими историками, подчеркивалась как современниками, так и в историографии более позднего времени [54]. Палата состояла из двенадцати постоянных комиссий, заседания которых не были публичными. Полномочий в сфере законодательства у нее было мало. Практически это была структура, инициировавшая законодательство. В связи с частыми изменениями в руководстве НФП и корпораций неоднократно менялся и состав советников. Согласно докладу Гранди о первых трех годах деятельности Палаты, представленному Муссолини, ей было достаточно десяти дней, чтобы принять 80 процентов законопроектов, и только в 23\% законопроектов были внесены поправки [55]. Законодательство обсуждалось часто. Вносились в него и поправки. Однако, как замечает один из исследователей, цитируя Боттаи, они явно не «выходили за границы технической и концептуальной критики» и всегда оставались в границах режима [56].

\section{Фашизм и социальный католицизм на Пире- нейском полуострове}

Если не считать одного года существования президентской диктатуры Сидониу Паиша в Португалии (1918), то диктатура Мигеля Примо де Ривера в Испании (1923-1930) была первой, в которой парламентаризм был заменен однопалатной системой представительства, основанной на принципах корпоративизма. Была создана единая партия режима - Патриотический союз (ПС), имевшая четкую политическую доктрину. Если Сидониу Паиш только наметил программу корпоративистского представительства, то каталонский генерал разработал политическую формулу современных диктатур, в которой корпоративизм являлся центральным элементом легитимации режима.

Возглавил переворот против либерального режима Мигель Примо де Ривера и обратился к стране с манифестом, в котором осудил социальные потрясения, сепаратизм и клиентелизм. Необходимость наведения порядка стала оправданием для установления «переходной диктатуры». Был проведен плебисцит по вопросу об изменении конституции и институализации нового режима. ПС стал партией, подконтрольной правительству. С целью интеграции под государственным контролем всех организованных групп интересов и упразднения профсоюзов, сформированных по классовому принципу, парламент формировался на основе системы корпоративизма, его полномочия были ограничены [57].

Тот факт, что диктатор был военным, не являлся препятствием для институализации режима. Диктатура Мигеля Примо де Ривера стала иллюстрацией идеи, согласно которой «существование единого национального интереса, присущего военному мышлению, совпадает с видением общего блага в модели органического государства» [58]. ПС в годы диктатуры Примо де Ривера выступал в роли партии режима. Несмотря на присутствие, хотя и ограниченного, плюрализма, позволявшего другим партиям действовать легально, ПС давал понять, что «в рамках режима может существовать только одна партия» [59].

ПС представлял собой попытку создания партии сверху вниз и являлся инструментом в руках диктатора и правительства. Эта партия была слабой структурой. Она не была способна в полной мере реализовать функции по формированию новой элиты, стать центральным органом, принимающим решения и самореализовалась лишь на уровне местного администрирования.

В 1927 г. в Испании была создана Национальная консультативная ассамблея, которая, скорее, сотрудничала с режимом, чем выполняла роль законодательного органа. Ассамблея была первой корпоративистской палатой в Европе межвоенного времени. В ее состав входили 400 представителей государства, местных властей, партии, муниципалитетов и профессиональных групп. Ее деятельность контролировалась министерством внутренних дел. Некоторые консерваторы, даже являвшиеся участниками этой ассамблеи, с подозрением относились к ее марионеточным функциям. Накануне падения режима общественности страны был представлен проект новой Конституции. Он предусматривал резкое усиление исполнительной власти и создание одной парламентской палаты, члены которой должны были выдвигаться ПС и избираться в равной мере на основе как прямого, так и корпоративистского избирательного права.

Некоторые из институциональных компонентов этого раннего диктаторского эксперимента на Пиренейском полуострове присутствовали и в Португалии - стране, в которой в XX веке просуществовала наиболее продолжительная диктатура. Этот режим до своего конца настаивал на своей корпоративистской легитимности [60].

Его становление и утверждение происходили следующим образом. 28 мая 1926 г. военный переворот положил конец парламентской республики. 
После с переворота и до институализации «нового государства» Салазара прошло семь лет нестабильности. Проект новой конституции, был представлен лидером восстания, генералом Мануэлем ди Оливейра Гомиш да Кошта всего через месяц после переворота. Этот проект гласил: «Новая конституция основывается на следующих принципах: национальное представительство создается прямым делегированием от муниципалитетов, экономических союзов, образовательных и духовных органов, с полной отменой индивидуалистического избирательного права и, как следствие, партийного представительства» [61]. Обсуждались и другие проекты. Однако приведенный пример демонстрирует важную роль корпоративистских альтернатив, утвердившихся в португальской элитарной, антидемократической политической культуре.

Первым политическим институтом, созданным диктатурой, была единая партия - Национальный союз (НС). Создание этой партии Салазаром в 1930 г. сопровождалось роспуском существовавших политических партий, в том числе Португальского католического центра (ПКЦ), членом которого был и сам Салазар. Инициаторами создания партии выступили Салазар и правительство при решающей поддержке госаппарата, особенно министерства внутренних дел и его представительств на местах. В манифесте НС, а также в инаугурационной речи Салазара перед членами партии в 1930 г., были ясно изложены намерения будущего диктатора. Он объявил о «создании социально-корпоративистского государства, которое будет следовать естественному устройству общества» [62].

Первый камень в фундамент социального корпоративизма в Португалии был заложен в Национальном уставе труда (НУТ) 1933 г. Многие заложенные в НУТ принципы, хотя и смягченные идеалами социального католицизма, были позаимствованы из итальянской Хартии труда [63]. После принятия НУТ первыми под удар попали португальские профсоюзы. Последующее законодательство предполагало создание целого ряда промежуточных органов, что должно было привести к созданию корпораций [64].

Социальный корпоративизм был сильно институализирован. Различные агентства охватили практически все социальные группы и профессии. Но до 1950-х гг., когда корпорации были, наконец, созданы, значительная часть представительства органических элементов нации выбиралась корпоративистским советом, в который входил Салазар и многие министры.

Становление конституционного проекта Салазара в начале 1930-х гг, а также созданных им ин- ститутов, продемонстрировали важную роль консервативных течений, которые поддерживали диктатуру. Особенно заметной была поддержка военных. Первый проект предусматривал создание корпоративистской системы выборов как президента, так и парламента. Однако в другой, последующий проект, представленный общественности в 1932 г., были внесены многочисленные изменения [65]. В результате он предполагал создание законодательного органа, состоящего из 90 депутатов, половина из которых избиралась прямым голосованием, а половина на основе корпоративистского избирательного права. Этот проект подвергся резкой критике со стороны некоторых военных чиновников, а также последователей Лузитанского интегрализма (ЛИ) и фашистского Национал-синдикалистского движения (НСД), возглавляемого Франсишку Ролау Прето. В свою очередь Церковь проявила озабоченность тем, что в конституции отсутствовало упоминание Бога [66]. Если военные чиновники критиковали корпоративизацию представительства, то НСД и ЛИ считали, что в проекте конституции слишком много места отведено республиканскому либерализму.

Окончательный вариант, утвержденный Салазаром и представленный на плебисцит, был компромиссным. Страна стала «унитарной и корпоративистской республикой», однако президент и Национальное собрание избирались на основе прямого, а не корпоративистского избирательного права. Конституция провозглашала создание представительного однопалатного органа. При этом часть депутатов Национального собрания должна была избираться на съезде правящей партии, а другая в ходе прямого голосования. Предполагалось также создание консультативной корпоративисткой палаты, которая должна была состоять из представителей функциональных интересов. По сравнению с исполнительным органом, независимым от парламента, Национальное собрание обладало значительно меньшими полномочиями. Корпоративистская палата, состоявшая из 109 доверенных лиц и заседания которой должны были проходить при закрытых дверях, отводилась роль вспомогательного и консультативного органа.

Несмотря на то, что члены палаты представляли функциональные интересы, небольшая группа лиц от административного блока назначалась корпоративистским советом во главе с диктатором. Именно эта группа, составлявшая в среднем 15\%, формировала элиту палаты и контролировала ее деятельность [67].

Анализ совокупности консультативных заключений, сделанных корпоративистской палатой на протяжении первого десятилетия ее деятельности, 
позволяет сделать вывод, что функции палаты в рамках диктаторской консультативной системы «позволяла ей проводить первые слушания относительно эффективности общественной политики и вносить предложения, касающиеся последствий тех мер, которые планировалось принять» [68]. Наконец, такой анализ позволил выявить подчиненный характер корпоратистской палаты по сравнению с Национальным собранием, поскольку ее консультативные заключения не обязательно учитывались во время дебатов в последнем [69]. Следует при этом подчеркнуть, что и Национальное собрание играло второстепенную роль, являясь, по сути, совещательным органом в отношении законодательной сферы. Оно было тесно связано с исполнительной властью и подчинялось ей, поскольку не могло не считаться с правилами режима, в котором действовал не принцип разделения властей, а принцип органического единства [70].

Несмотря на то, что за время своего длительного существования режим Салазара и франкизм конвергировались как формы авторитаризма, стали очевидны их различия, обусловленные спецификой их происхождения, а также их отличие от диктатуры Примо де Риверы. По иронии судьбы, одной из ведущих фигур испанского корпоративизма был каталонец Эдуардо Аунос - вдохновитель двух корпоративистских парламентов и институтов в испанских диктатурах. Будучи представителем либерально- консервативной элиты, он занимал пост министра труда при режиме Примо де Ривера. В качестве консультанта Фаланги Аунос приобрел известность как автор Хартии труда. Франко назначил его министром юстиции. Между тем, эта кажущаяся преемственность фигур и институтов испанского авторитаризма XX века не может скрыть того факта, что истоки и изначальная конфигурация франкизма имели мало общего с диктатурой Примо де Ривера, режимом Салазара в Португалии или с любой из диктатур, установленных в странах Центральной и Восточной Европы.

Режим Франко был продуктом кровавой гражданской войны. Основной характеристикой первых лет его существования был радикальный разрыв с демократией, поскольку он в гораздо большей степени был вдохновлен динамикой фашизма. Как отмечает американский исследователь Стэнли Пэйн, в первые годы франкизма «формальная структура режима Франко была самой произвольной структурой в мире» [71]. Франко официально провозгласил тоталитарную модель. После формирования единой партии, созданной путем насильственного объединения групп, которые поддержали Франко во время гражданской войны, ИТФ ХОСН (Испанская традиционалистская Фаланга и ХОСН) под руководством
Фаланги - даже под властью Франко - не только удалось создать партийный аппарат и мощные вспомогательные организации, но и получить такой уровень доступа к сегментам новой политической системы, который был сопоставим только с НФП в Италии Муссолини [72].

Социальный корпоративизм был основным компонентом франкизма и его институтов, которые начали вырисовываться в ходе гражданской войны в районах, контролируемых националистами, где существовали напряженные отношения между национальной синдикалистской моделью Фаланги и группами, более близкими к консервативным католикам. Не все из этих конфликтов имели доктринальный характер. Некоторые были выражением опасений внутри Фаланги по поводу того, что ее роль в создании новой корпоративистской структуры будет сокращаться. Эти опасения не подтвердились, так как и Хартия труда 1938 г. и институциональная структура франкистской конфедерации труда обеспечили Фаланге центральную роль [73]. В 1940 г., когда закон о синдикалистских союзах предписал большинству рабочих, техническому персоналу и работодателям вступать в один из 27 многофункциональных, вертикальных и отраслевых синдикатов, этот процесс контролировался фалангистами, как на государственном, так и партийной уровне [74]. Вместе с тем, позднее, несмотря на фашистскую риторику, сопровождавшую создание корпоративистской системы, в связи с отстранением от дел в 1941 г. Сальвадора Мерино - фалангистского директора синдикатов, влияние партии уменьшилось. Кроме того, и это более важно, первоначальная концепция вертикальных синдикатов была заменена на принцип, согласно которому работодатели и работники были представлены в отдельных секциях.

В 1940 г. политический комитет ИТФ ХОСН во главе с Рамоном Серрано Суньером, представил первый проект конституционных законов, что также предвосхитило создание корпоративистского парламента. В общей сложности 20 из 37 статей проекта были посвящены этому органу власти. Как отмечает Стэнли Пэйн, Серрано Суньер поддержал «еще более профашистскую политическую систему, чем та, которую был готов разрешить Франко» [75]. Наиболее спорным предложением, содержащимся в этом проекте, была институализация политического комитета ИТФ ХОСН в качестве коллегиального координирующего органа между государством и движением: своего рода франкистская версия Большого фашистского совета Муссолини. Однако консерваторы посчитали, что такой орган будет означать вмешательство партии в дела государства. Поэтому Франко отклонил это предложение [76]. 
В 1942 г. решение Франко создать корпоративистский парламент стало важным шагом к консолидации режима, особенно на фоне того, что фашисты начали проигрывать Вторую мировую войну. Корпоративистский парламент явился главной институциональной инновацией этого этапа. Религия и органическо-этатистские взгляды на отношения между государством и обществом сыграли здесь центральную роль [77]. Испанские христианские корни, исключительное место каудильо в истории, а также народное представительство в рамках органической демократии должны были стать основными элементами легитимности консолидированного франкизма после эпохи фашизма [78].

Испанский корпоративистский парламент кортесы - был создан как инструмент сотрудничества с Франко. По закону, регулирующему деятельность кортесов, этот новый законодательный орган должен был служить «для выражения противоположных мнений внутри единого режима». Франко, как глава государства, должен был по-прежнему оставаться «верховной властью и диктовать правовые нормы», а кортесы представлять «ценный инструмент сотрудничества в выполнении поставленной задачи» [79].

Первый состав кортесов состоял из 423 доверенных, из которых 126 были членами национального совета единой партии, 141 представляли синдицированные организации, 50 назначались лично каудильо, а остальные были представителями муниципалитетов, семей, ассоциаций свободных профессий и т.д. [80]. Кабинет министров и глава судебной власти также являлись членами кортесов [81]. Подавляющее большинство доверенных были государственными служащими; следовательно, вес бюрократии в нем был очень существенным [82]. Единственным изменением в составе кортесов стало включение в их состав в 1967 г. 108 представителей семей, официально избранных на основе ограниченной избирательной системы. Само собой разумеется, что кабинет министров был ответственен перед главой государства, а кортесы созданы, чтобы вырабатывать рекомендации и обсуждать законы, предлагаемые правительством. Чтобы избежать создания неформальных группировок внутри кортесов, их президент назначался самим Франко, а руководители комиссий - президентом кортесов. В период диктатуры институциональных изменений было немного.

\section{Австрия при Дольфусе}

Непродолжительная институализация диктатуры Энгельберта Дольфуса в Австрии была самым ярким воплощением попытки авторитарного слия- ния социального и политического корпоративизма под гегемонией консервативного католицизма. В Австрии мечту о корпоративизме разделяли фашисты, хеймвер (народное ополчение) и католики, однако гегемония при ее институционализации принадлежала политическому католицизму [83]. С начала 1920-х гг. Христианско-социальная партия (ХСП) выдвинула предложения о частичной корпоративизации политического представительства, а к началу следующего десятилетия под руководством Игнаца Зайпеля ХСП порвала с демократическими установками. Игнац Зайпель был одним из самых заметных сторонников корпоративистского варианта, который он рассматривал как истинную демократию для Австрии [84].

В 1929 г. ХСП снова выдвинула на передний план некоторые из его предложений 1919 г. по созданию корпоративистской верхней палаты. Они были отвергнуты Социал-демократической рабочей партией Австрии (СДРПА). Однако когда Дольфус приостановил действие конституции, распустил парламент, запретил политические партии и начал управлять страной, будучи наделенным чрезвычайными полномочиями, переход к авторитаризму был осуществлен путем институализации корпоративистского представительства, формализованного в конституции 1934 г. Влияние, которое оказали фашисты из хеймвера на выбор корпоративистского варианта, нельзя недооценить, так как в рамках нового режима они располагали наибольшим политическим весом. Начиная с 1930 г., будучи близки к итальянской модели фашизма и идеям Отмара Шпанна, они неоднократно предлагали проекты корпоративизации политической системы.

Конституция 1934 г. установила переходный период для реализации корпоративистской модели. Поэтому когда Гитлер в 1938 г. вторгся в Австрию, корпоративизация во многом еще оставалась только на бумаге. Согласно новой конституции, дуумвират президента и канцлера обеспечивал полноту полномочий последнему. В электоральном плане была создана система органического голосования, а законодательный орган заменен четырьмя консультативными структурами, представляющими государство, культуру, экономику и регионы. Эти консультативные органы направляли своих представителей в федеральный парламент, состоявший из 59 членов.

В корпоративистских органах было лишь на одного делегата больше, чем в федеральном парламенте. Напомним в этой связи, что, как и везде, где отсутствовали организованные корпорации (а к 1938 году в Австрии их было создано только две из намеченных семи), эти органы формировались из 
лиц, назначаемых президентом и канцлером. Не удивительно, что ХСП доминировала во многих из этих консультативных структур, хотя первоначально хеймвер имел в них больше мест, чем в парламенте в демократический период [85].

Правительство пользовалось большой автономией по отношению к этим консультативным структурам, которые были наделены только ограниченным и частичным правом вето. При этом последнее можно было обойти при помощи исполнительной власти. Фактическое подчинение законодательной власти правительству оставляло мало места для публичного выражения мнений по вопросам государственной политики, не санкционированных исполнительной властью [86]. Действительно, между 1934 годом и концом режима после нацистского вторжения, 69,31\% законодательных актов было принято непосредственно советом министров [87].

Главным элементом институализации нового режима стало созданное в 1933 г. единое политическое движение - Отечественный фронт (ОФ), в который были делегированы члены ХСП и хеймвера. Дольфус создал эту организацию как централизованный инструмент, полностью послушный своему основателю. Однако она, как уже отмечалось, оставалась «бюрократической организационной оболочкой, не получившей динамичного развития и не обретшей собственного значения» [88.] Преемнику Дольфуса - Курту Шушнигу - удалось сократить влияние хеймвера и заставить его частично объединиться с ОФ. Однако существование такой конфигурации однопартийной системы было непродолжительным.

\section{Проблемы корпоративизма в конкурентных авторитарных режимах Центральной и Восточной Европы}

Некоторые межвоенные режимы оказались «в состоянии функционировать в формально парламентских рамках при наличии правящей правительственной партии, получившей большинство в результате коррупционных избирательных технологий, кооптации представителей политических элит, а также благодаря объявлению вне закона или преследованию тех, кто был против правящего режима, допуская при этом наличие слабой и ручной оппозиции» [89]. Если структуры правительств разделяли взгляды консерваторов и правых радикалов, этим режимом, как правильно отмечает Эндрю Янош, разрешались существенные компромиссы, что приводило даже к установлению режимов со слабыми политическими институтами [90]. Примерами таких режимов можно с полным основанием считать межвоенные Венгрию и Польшу.
Политическая стабилизация в Венгрии после успешной контрреволюции породила гибридный режим под патерналистским и твердым руководством адмирала Миклоша Хорти. Однако консолидация его режима произошла только в 1921 г., когда премьер-министром страны стал граф Иштван Бетлен. Он, как и многие другие консервативные европейские лидеры, считал, что демократия «подходит только для богатых, хорошо структурированных стран с высокой культурой». Венгрия же в 1920 г. такой страной не являлась, занимая срединное место «между необузданной свободой и неограниченной диктатурой» [91]. Бетлен провел реформу избирательной системы, которая позволила ему, несмотря на сокращение послушного электората, провести открытое клиентелистское голосование в сельской местности, сохранив тайное голосование в крупных городах.

Вторым шагом премьера было создание правительственной партии, призванной обеспечить, прибегая к политическому давлению и клиентелистским процедурам, свое господство в системе. Эта роль была отведена Партии единства (ПЕ), которая, начиная с 1922 г., последовательно выигрывала полуконкурентные выборы , состоявшиеся в годы правления Бетлена [92]. К палате представителей, в которой доминировала ПЕ, была добавлена, восстановленная в 1925 г. верхняя палата, которой был придан корпоративистский характер. В нее вошли представители трех религиозных конфессий, 36 профессиональных и экономических палат, 76 представителей округов и муниципалитетов, 48 пожизненных членов, назначенных Хорти, и 38 аристократов.

Когда в 1932 г. Хорти, вопреки желанию, назначил премьер-министром Дьюлу Гембеша, режим начал еще больше смещаться вправо. И это несмотря на раскол в рядах венгерских праворадикальных сил. Гембеш, известный в кругу политических противников как «Гемболини» (намек на его подражание Муссолини), был лидером правого военизированного объединения и близким соратником Хорти, который, как тогда считалось, смягчал самые радикальные стороны стратегии Гембеша. Последний реорганизовал ПЕ, переименовал ее в Партию национального единства (ПНЕ), придав ей большую ориентацию на экстра-электоральную политическую деятельность, обеспечил ее небольшим военизированным сектором и поставил перед ней задачу массовой мобилизации сторонников.

Вдохновленный итальянской Хартией труда, Гембеш также планировал введение системы обязательного представительства организованных интересов, основанной на вертикальном корпоративизме с несколькими профессиональными палатами, в 
которых представители работодателей и работников должны были бы совместно решать вопросы труда. Он попытался ликвидировать двухпалатный парламент (посредством создания государственного совета, заменяющего сенат) и представил план создания нового парламента, состоящего из выборных представителей и делегатов от муниципальных образований, государственных ведомств и профессиональных корпораций [93]. В 1935 г. планы по институализации корпоратистской однопартийной диктатуры были представлены во время избирательной кампании. Однако в следующем году Гембеш умер, а с ним рухнули и его планы. Создание корпоративистской системы было снято с повестки дня, а реорганизация партии приостановлена [94]. Некоторые ее организации были распущены, а самой ей возвращен первоначальный облик «избирательной машины, опирающейся на местную бюрократию» [95].

Предвосхищая дискуссию о гибридных или полудемократических режимах, развернувшуюся в начале XXI века, в 1972 г. один специалист по истории Польши определил межвоенный польский режим как «полуконституционную управляемую демократию» [96]. Действительно, когда Юзеф Пилсудский возглавил государственный переворот, разрушивший в 1926 г. польскую парламентскую демократию, это не привело к быстрому переходу к диктатуре. Режим Пилсудского основывался на демократическом национализме, который очень отличался от контрреволюционных корней венгерской правящей элиты того же времени. Однако некоторые аспекты, связанные с классификацией польского режима, незначительно отличаются от реалий режима Бетлема в Венгрии. Концентрация власти, создание коалиционной партии и Беспартийного блока сотрудничества с правительством (ББСП), поддержка генерала парламентом и, наконец, представление новой конституции - вот отличительные черты правления Пилсудского [97].

Пилсудский обладал многочисленными полномочиями. Однако парламент, вопреки тому, что число депутатов уменьшилось, и он стал подконтролен, по-прежнему создавал президенту трудности, поскольку в нем все еще сохранялась значительная степень плюрализма. В 1935 г. новая конституция отразила попытку ограничить многое из того, что уже было функциональной практикой режима. Исполнительная власть стала подотчетной президенту, а не парламенту. Статья 2 гласила, что президент отвечал за судьбы государства только «перед Богом и историей» [98]. Конституция предусматривала двухпалатную систему; однако количество законов, которые могли быть приняты с помощью указов, увеличивалось. Решительный разрыв с либеральным парламентаризмом был закреплен избирательными законами, фиксировавшими состав законодательного органа. Новое заключалось в определении статуса выборщиков: частных лиц, избираемых прямым голосованием, но предварительно выдвигаемых органическим методом.

Парламент (Сейм) состоял из 209 депутатов. Страна была разделена на 104 избирательных округа, от которых выдвигалось по два кандидата. Кандидатов отбирали местные комиссии во главе с их президентами, которых назначало правительство. Эти комиссии состояли из делегатов от местных органов власти, корпораций, торгово-промышленных палат, промышленности и сельского хозяйства, свободных профессий и профсоюзов. Масштаб манипуляций правительства был впечатляющим, что обеспечивало наличие однородного и послушного Сейма. Позже верхняя палата был сокращена до 96 членов, одна треть которых назначалась президентом, а две трети избирательными советами. Сами же советы избирались учреждениями [99].

Оппозиционные партии отреагировали на эту ситуацию бойкотом выборов.

Пилсудский умер в 1935 г. Польша осталась диктатурой без диктатора. Во главе страны оказались его ближайшие военные соратники, а фракционность режима возросла. Институциональная хрупкость режима после роспуска ББСП привела в 1936 г. к созданию Лагеря национального единства (ЛНЕ) партии режима, которая была мощнее, чем ее предшественница, лучше структурирована и больше походила на единую партию. Адам Коц - молодой последователь Пилсудского - организовал в партии молодежную секцию, которую намеревался объединить с фашистской Фалангой, имевшей более клерикальную и корпоративистскую политическую программу. Коц также предложил ликвидировать профсоюзное движение и «создать систему корпораций по фашистской модели» в духе программы ЛНЕ. Однако этот вариант не был претворен в жизнь, а в 1939 г. Польша была, как известно, оккупирована нацистскими войсками [100].

Что касается Румынии, то там короткий диктаторский эксперимент не привел к созданию консолидированного режима, но его четкой целью была институализация однопартийной системы. Когда 10 февраля 1938 г. король Кароль II приостановил действие конституции и, тем самым, ввел королевскую диктатуру, его первыми шагами были роспуск политических партий, создание единой партии Фронт Национального Возрождения (ФНВ) и проведение плебисцита о новой корпоратистской конституции. Все это происходило в один и тот же год. Фашисты из «Железной гвардии» (Легиона Михаи- 
ла Архангела), руководимой Корнелиу Кодряну Зеля, не отреагировали на королевский государственный переворот и на первых порах признали роспуск Легиона [101]. Королевская диктатура стремилась позаимствовать идеологическую привлекательность «Железной гвардии», пропагандируя «органический национализм, ценности семьи, церкви и святости труда» [102].

По конституции, новый парламент избирался представителями отраслевых организаций сельского хозяйства, промышленности, торговли, профессиональных групп и интеллигенции. Министров назначал король, и они были подотчетны только ему. К королю перешла от парламента и законодательная инициатива, Стратегом экономической политики королевской диктатуры стал видный теоретик корпоративизма. Маноилеску. Казнив Кодряну и других фашистских лидеров, король, под давлением нацистов, требовавших их интеграции в существующий режим, реорганизовал свою единую партию, переименовав ее в Партию Нации (ПН). Партия включила в свои ряды оставшихся фашистов. Членство в ней стало обязательным для всех служащих общественных и корпоративных учреждений.

В 1940 г. Кароль II отправился в изгнание, оставив сына в качестве председателя дуумвирата, образованного генералом Антонеску и «Железной гвардией», во главе которой встал Хория Сима. В течение короткого времени «Железная гвардия» была единой партией «Национал-легионерского государства». Причем никаких инициатив, направленных на корпоративистскую реорганизацию, не выдвигалось. После того, как Антонеску вывел Легион из правительства, режим приобрел облик военной диктатуры с элементами плебисцитной системы [103].

Пронацистская диктатура Антонеску, сложившаяся после устранения фашистской «Железной гвардии», оказалась плохо институализированной. Иной была ситуация, сложившаяся в католической Словакии. Когда в 1939 г. было создано Словацкое государство, ставшее германским протекторатом, то многочисленной наследницей Словацкой народной партии Андрея Глинки (ГСНП) стала единая партия, во главе которой стал его преемник, католический священник Йозеф Тисо, провозгласивший девиз «Один Бог, один народ, одна партия» [104].

Еще в 1931 г., находясь под влиянием австрийской католической церкви и ее видного деятеля Игнаца Зайпеля, Тисо «отвернулся от парламентской демократии, поддержав католический корпоративизм, представленный в энциклике «Quadragesimo Anno» [105]. Как утверждал Тисо в 1930 г., «нация представляет собой единый набор корней, обычаев и языка, составляющих органическое целое [106]. Однако, несмотря на свою склонность к диктатуре и наличие единой партии, Тисо пришлось делить власть в стране с Войтехом Тука, который придерживался более радикальных взглядов. Последний с согласия немцев стал премьер-министром, и немцы пожелали оставить его на этой должности.

Конституция 1939 г. провозгласила Словакию католическим государством, в котором «народ участвует во власти через ГСНП», которая будучи действительно, единой, взяла под свой контроль парламент [107]. Вновь созданный Государственный совет превратился в корпоративистскую верхнюю палату - совещательный орган при Тисо, который стал президентом. Членами Государственного совета были премьер-министр, президент парламента и члены, назначаемые Тисо, от единой партии и каждой корпорации. Был создан также Совет подобный Большому фашистскому совету Муссолини. Этот Совет отбирал кандидатов в парламент [108].

Насаждение корпоративистской системы, получившей наименование «Христианский солидаризм» стало вскоре программой действия. Все словаки были обязаны присоединиться к одной из четырех корпораций, которые заменили профсоюзы, а политические кадры в этих корпорациях должны были быть членами единой партии «Партии национального единства» (ПНЕ) [109]. Как и в других диктатурах, институционализация социального корпоративизма вызвала сопротивление промышленников, которые осудили этот план как «революционный» [110].

Новая конституция, составленная под влиянием салазаровской Португалии и Австрии Дольфуса, должна была примирить либеральный парламентаризм и корпоративизм, и навести порядок внутри единой партии, в которой самой влиятельной была прокорпоративистская клерикальная фракция [111]. Вместе с тем, недолгое существование режима, деятельность более радикальной фракции Тука, а также влияние нацистской Германии и немецкого меньшинства помешали дальнейшему развитию страны в направлении корпоративистской системы [112].

Корпоративизм также ненадолго возник в Болгарии, а также в Греции в годы правления Метаксаca. В Болгарии после государственного переворота, совершенного в 1934 г. полковником Дамианом Вельчевым, парламент и политические партии были распущены. Целью этого акта было намерение установить в стране корпоративистское представительство. Основой избрания трех четвертей нового парламента должны были стать семь корпораций (сословий) [113]. Между тем планы создания единой партии были заблокированы царем Борисом. Почув- 
ствовав угрозу своему положению, он принял на себя всю полноту власти и в следующем году ввел режим королевской диктатуры с контролируемым парламентом и такими избирательными законами, которые должны были обеспечить ему контроль над палатой [114].

В Греции «режим 4 августа» 1936 г. был установлен вслед за государственным переворотом, осуществленным премьер-министром Метаксасом - главой небольшой консервативной, антипарламентской партии роялистов. После роспуска парламента и политических партий, Метаксас не создал единой партии, так как король не согласился бы с этим. Новый диктатор возлагал надежды на создание официальной «Национальной молодежной организации» (HМO), положившей в основу своей деятельности итальянскую фашистскую модель. Через несколько недель после переворота программа Метаксаса стала ясна; ее 14 пунктов предполагали «спокойную модернизацию общества на национальной корпоративистской основе, с тем, чтобы появилось по-настоящему национальное представительство» [115]. Режим приступил к реализации «программы «горизонтальной» реструктуризации экономических и трудовых отношений в такой форме, что стало ясно влияние на него фашистской Италии и салазаровской Португалии с их корпоративистскими экспериментами. В первую очередь это касалось планов конституционной реформы [116]. Эти планы стали более конкретными, когда Метаксас разработал новую систему национального делегирования [117]. Согласно нескольким источникам, негативное отношение короля к корпоративистскому представительству привела к отсрочке проекта.

\section{Корпоративизм и президентские диктатуры в странах Балтии}

Образование персонифицированных авторитарных режимов в молодых странах Балтии прошло очень быстро. В 1926 г. военный государственный переворот в Литве привел к власти Антанаса Сметону. В 1934 г. почти синхронная серия переворотов привела к установлению президентских диктатур в Эстонии и Латвии. Советское вторжение в 1940 г. положило конец диктатурам. Наиболее продуманные попытки институализации корпоративистских режимов в регионе были предприняты Пятсом в Эстонии и Карлисом Ульманисом в Латвии.

Несмотря на влияние католической церкви и ее конкордат с Литвой, стремительная концентрация власти президентом Сметоной вызвала ряд конфликтов между правящей партией националистов и христианскими демократами, которые первоначально были вовлечены в проавторитарную коалицию. К концу 1930-х гг. эта партия имела молодежное крыло и собственную милицию. Парламент превратился в совещательный орган, а президент избирался чрезвычайными представителями нации, делегированными правящей партией. Однако стремление официальной партии играть более активную роль не было поддержано президентом [118].

Корпоративистские экономические органы были созданы в 1930-е гг. И хотя идею органического государства выдвинули оппозиционные христианские демократы, ее реализация стала центральной в политическом дискурсе Сметоны [119]. Стратегия контроля над парламентом включала в себя избирательный процесс, в рамках которого кандидаты выдвигались муниципалитетами, а не к тому моменту распущенными политическими партиями. Правящая партия получила подавляющее большинство в парламенте, имевшем простые консультативные полномочия. Сметона провозглашен вождем народа, а Литва стала первым авторитарным однопартийным государством стран Балтии [120].

В Эстонии Константин Пятс, заставив после государственного переворота 1934 г. парламент замолчать, распустил в 1935 г. политические партии и попытался создать единую партию «Союз Отечества» (СО), задачей которой была поддержка президента. Эта партия не очень отличалась по своим корням и изначальным функциям от таких аналогов, как салазаровская НС в Португалии. Идея организации по профессиональным группам продвигалась в качестве альтернативы партиям и парламентаризму, поскольку какое-то время корпоративистские организации были любимым детищем Пятса [121]. Между 1934 и 1938 гг. режим создал 15 профессиональных палат, представители которых впоследствии получили места в верхней палате национального собрания. В 1935 г. был также создан переходный орган для консультирования правительства. Он состоял из 15 членов, избираемых профессиональными палатами и 10 членов, назначаемых президентом. Политическая система не была полностью корпоративистской, так как по конституции 1938 г. была создана двухпалатная система с палатой представителей, в которую вошли 80 депутатов, избранных прямым голосованием, и корпоративистской верхней палатой, состоявшей из 40 членов, представлявших административные ведомства, профессиональные органы, а также церковные и светские организации.

В Латвии лидер правого «Аграрного союза» (ЛАС) Карлис Ульманис после нескольких попыток пересмотра конституции с целью ограничения парламентской власти ввел осадное положение. Парламент был, в конечном счете, распущен вместе с по- 
литическими партиями, в том числе и его собственной. Однако, в отличие от своих балтийских соседей, Ульманис не создал официальную политическую партию. Тем не менее ему удалось мобилизовать членов прежней партийной элиты. Изначально Ульманис осуществлял правление, действуя через правительство, в затем, как только истек срок президентского мандата, объединил должности премьер-министра и президента.

Институализация корпоративизма в Латвии была самой полной из всех стран Балтии, и историки до сих пор спорят о том, какие внешние факторы, включая опыт Италии и Австрии, оказали влияние на этот процесс [122]. В 1934-1938 гг. были созданы в общей сложности шесть корпораций, а старые ассоциативные и синдикалистские структуры были упразднены. Корпоративистские палаты находились под контролем соответствующих министерств, которые назначали большинство членов палат. Режим также создал национальный экономический совет и национальный совет по культуре для надзора за деятельностью соответствующих палат. Хотя некоторые наблюдатели отмечают, что Улманис хотел создать корпоративистский парламент, заменив им «пленарные заседания политических партий», этого так и не произошло [123].

\section{Заключительные замечания}

Корпоративизм часто и с полным основанием связывают с католической политической культурой начала XX века, несмотря на то, что он был признан в том числе и фашизмом - авторитарной альтернативой либеральной демократии. Хотя он и фиксировался в институтах некоторых демократических режимов, только в условиях диктатуры происходило существенное переформатирование политических режимов в духе корпоративистских установок [124]. Успех гибридизации авторитарных политических институтов Европы, происходившей в первой половине XX века, является наглядной иллюстрацией повсеместного укоренения корпоративистских учреждений. Этот опыт проиллюстрировал не только прагматичное восприятие авторитарных институтов, но и то, каким образом они были использованы диктаторами, не имевшими прямой связи с культурой католического или фашистского корпоративизма, характерного для южной Европы. Несмотря на наличие некоторых вариаций, идеология нечленимого национального интереса, типичная для аполитичного военного мышления и консервативных антидемократических элит, оказалась вполне совместимой с органически-этатистской основой корпоративистского представительства. Поэтому казавшийся успешным практический опыт некоторых режимов и привел к такому быстрому распространению корпоративизма [125].

Отличительной чертой всех межвоенных диктатур была замена государственных институтов. Что касается социального корпоративизма, то преимущественное влияние в этой сфере итальянского фашизма представляется вполне очевидной. Первый принцип итальянской Хартии труда в его явно тоталитарной форме был воспроизведен во всех межвоенных европейских диктатурах: «Итальянская нация, гласил он, ... это моральный, политический и экономический союз, который во всей полноте реализуется в фашистском государстве».

Проекты авторитарных конституций и хартий труда, хотя и в менее этатистских версиях, как правило, начинались с провозглашения органического принципа. Во многом пронизывал межвоенный период и социальный корпоративизм как форма принудительно-государственной интеграции групп интересов в парагосударственные структуры и уничтожения автономных профсоюзных движений.

Политическая инженерия, с помощью которой диктатуры осуществляли кооптацию сложных структур групп интересов, а также настойчивый поиск легитимизации, стали в 1930-е гг. неуклонной программой действий. Сравнительный анализ хартий труда или подобных им законодательных актов диктаторских режимов убедительно демонстрирует функцию ролевой модели Хартии труда фашистской Италии в 11 диктатурах. При этом их национальные модификации были отражением специфики форматируемых коалиций (см. таблицу 1).

В «новом государстве» Португалии, в Австрии при Дольфусе, в Словакии при Тисо и даже в Испании при Франко политический католицизм сказывался в большей мере, чем в вишистской Франции или, например, в Восточной Европе. Тем не менее, в общем наследии этот критерий был определяющим для создания «посреднических структур» между групповыми интересами, для роспуска независимых профсоюзов и для передачи государству руководства переговорными структурами в интересах защиты режима. Если подобные институты оставались лишь на бумаге, как это было в Греции при Метаксасе или в Болгарии при Вельчеве, их очертания все равно схожи.

Несмотря на примат социального корпоративизма, центральную роль в гибридизации институционального развития межвоенных диктатур играла система политического представительства, альтернативная парламентской демократии. При этом опыт фашистской Италии сказывался в значительно меньшей степени на распространении корпоративистского законодательства. Анализ конституций и 
хода институциональных реформ свидетельствует, что роль в этом деле салазаровской Португалии и Австрии при Дольфусе была гораздо большей.

Не следует недооценивать и влияния авторитарных конституций, поскольку они служили укреплению дорвавшихся до власти коалиций. В начале установления авторитарных режимов неопределенность ситуаций была очень велика. Отсюда, особая значимость провозглашения новых конституций «единственного ключевого механизма, посредством которого политические субъекты, помимо диктатора, могли кодифицировать свои права и интересы» [126]. В то же время власть партий и законодательных органов в ряде случаев ограничивала в чем-то пространство доминирования правящей группы.

Разнообразие законодательных органов, установленных авторитарными конституциями, предполагало доминирование смешанных законодательных систем, единых или просто правящих партий и корпоративистских палат. Очень немногие диктаторы в межвоенной Европе располагали с самого начала такой концентрацией власти, какая была у генерала Франко в 1939 г., Большинство из них испытывали большие трудности с институциональным устройством устанавливаемых режимов. Они были вынуждены предоставить места в своих новых институтах тем видным членам коалиций, которые привели их к власти. «Институционализированное взаимодействие между диктатором и его союзниками вело к большей прозрачности отношений между ними, и в силу своей формальной структуры, институты обеспечивали публично считываемый сигнал готовности диктатора делиться своей властью» [127].

Вместе с тем, каким бы привлекательным ни был принцип корпоративистского представительства для авторитарных правителей, создание корпоративистских законодательных органов протекало в некоторых диктатурах гораздо сложнее, даже тогда, когда оно было частью их программы. В некоторых странах, например, в Греции и Болгарии, создание корпоративистских законодательных органов было заблокировано боявшимися потерять власть монархами, в то время как в других, например, в хортистской Венгрии, диктаторы были патерналистскими правителями, или, как в Португалии, где был первоначально достигнут компромисс с сегментами консервативных либеральных партий, приведший к институционализации двухпалатной системы с корпоративистской палатой и парламентом, контролируемым правящей партией.

Очень немногие межвоенные европейские диктатуры существовали без единой или правящей партии, и отношения между диктаторами и их партиями, особенно теми, которые существовали до захвата власти, были сложнее, чем допускают негибкие версии дихотомии: фашизм и авторитаризм. Внутренняя дилемма, способствующая трансформации единой партии как правящего института диктатуры в инструмент правления лидера также не вписывается в жесткие дихотомии [128]. Создание единой политической партии не следует отождествлять с переходом к правлению на основе этой партии [129]. И на практике единая партия не всегда являлась правящим институтом в большинстве межвоенных диктатур. Скорее, она была одним из нескольких институтов [130].

В некоторых интерпретациях фашизма проводится существенное различие между партиями отдельных межвоенных диктатур, как фашистскими так и нефашистскими. Однако установленная склонность этих диктатур к созданию единых партий дает все основания предполагать, что они выполняли важные общие функции: инструмента лидера, средства кооптации элит и предотвращения фракционности, орудия достижения политической монополии на рекрутирование элиты, а также сдерживания угроз, исходящих от таких институтов, как вооруженные силы.

Независимо от времени появления режима (будь то до начала диктатуры или в результате ее создания сверху после падения предыдущей власти) или природы партий (массовых или элитарных), они выполняли аналогичные функции в законодательных органах новой политической системы и как единые, и как правящие партии. Они обеспечивали в большинстве межвоенных диктатур институционализированное взаимодействие между диктатором и его союзниками, а также политический контроль над корпоративистскими институтами.

Взаимопроникновение политического и социального корпоративизма, а также наличие единой партии, являясь отличительными чертами институциональных переходов в европейских диктатурах, ставят под сомнение некоторые жесткие дихотомические интерпретации межвоенного фашизма [131].

\section{Примечания}

1. Вслед за Альфредом Степаном и Хуаном Линцем мы используем это выражение для обозначения «видения политического сообщества, в котором составные части общества гармонично сочетаются ..., а также исходя из предположения, что такая гармония требует власти и единства гражданского общества, достигаемого с помощью «архитектонических действий органов государственной власти», - отсюда, «органический этатизм». См.: Stepan, A. The State and Society: Peru in Comparative Perspective. - Princeton, NJ, 1978; Linz, J.J. Totalitarian and Authoritarian Regimes. Boulder, CO, 2000. - P. 215-217. 
2. Lewis, P.H. Authoritarian Regimes in Latin America. Dictators, Despots, and Tyrants. - Lanham, MD, 2006. P. 129-154; Les Expériences Corporatives dans l'Aire Latine / Ed. by D. Musiedlak. - Bern, 2010; Parla, T.; Davison, A. Corporatist Ideology in Kemalist Turkey. Progress or Order? - Syracuse, NY, 2004.

3. Perlmutter, A. Modern Authoritarianism: A Comparative Institutional Analysis. - New Haven, CT, 1981. - P. 10.

4. Manoilescu, M. Le Parti Unique: Institution Politique des Régimes Nouveaux. - Paris, 1936. - P.. viii.

5. Manoilescu, M. Le Siècle du Corporatisme. - Paris, 1934; Manoilescu, M. Le Parti Unique.

6. Charisma and Fascism in Interwar Europe / Eds. by A.C. Pinto, R. Eatwell and S.U. Larsen. - London, 2007.

7. Более половины всех авторитарных режимов XX века, «инициированных военными силами, или партиями, или теми и другими вместе были частично или полностью персонализированы в течение трех лет с момента первоначального захвата власти». См.: Geddes, B. Stages of development in authoritarian regimes // World Order after Leninism / Eds. by V. Tismaneanu, M.M. Howard and R. Sil. - Seattle, WA, and London, 2006. - P. 164.

8. Ruling Elites and Decision-Making in Fascist-Era Dictatorships / Ed. by A.C. Pinto. - New York, NY, 2009.

9. Geddes, B. Stages of development ... - P. 185.

10. Perlmutter, A. Modern Autoritarianism ... - P. 11.

11. Ghandi, J. Political Institutions under Dictatorship. Cambridge, 2008. - P. 29.

12. Ibid. - passim.

13. Ibid. - P. viii.

14. Geddes, B. Stages of development ... - P. 164.

15. О типологии результатов взаимопроникновения режимов в этот период см.: Weyland, K. The diffusion of regime contention in European democratization, 18301940 // Comparative Political Studies. - 2010. - Vol. 43. P. $1148-1176$.

16. Conway, M. Catholic politics or Christian democracy? The evolution of interwar political Catholicism // Political Catholicism in Europe, 1918-45 / Eds. by W. Kaiser and H. Wohnout. - Vol. 1. - London, 2004. - P. 235-51.

17. Morck, R.; Yeung, B. Corporatism and the ghost of the third way // Capitalism and Society. - 2010. - Vol. 5, No. 3. - P. 4

18. Cardoso, J.L.; Mendonça, P. Corporatism and beyond: An assessment of recent literature // ICS Working papers. Vol. 1. - University of Lisbon, 2012.

19. Schmitter, P.C. Still the century of corporatism? // The New Corporatism: Social-Political Structures in the Iberian World / Eds. by F.B. Pike and T. Stritch. - Notre Dame, IN, 1974. - P. 94.

20. Bastien, C.; Cardoso, J.L. From homo economicus to homo corporativus: A neglected critique of neo-classical economics // The Journal of Social Economics. - 2007. Vol. 36. - P. 118-27.

21. Dard, $O$. Le corporatisme entre traditionalistes et modenisateurs: Des groupements aux cercles du pouvoir // Les expériences corporatives ... - P. 67-102.
22. Williamson, P.J. Corporatism in Perspective. - London, 1989. - P. 32.

23. Payne, S.G. Franco y José António: El Extraño Caso del Fascismo Español. - Madrid, 1997. - P. 116.

24. Ibid. - P. 178.

25. Garcia, F.B. El Sindicalismo Vertical: Burocracia, Control Laboral y Representación de Intereses en la España Franquista (1936-51). - Madrid, 2010.

26. Luyten, $D$. La réception des corporatismes étrangers et le débat sur le corporatisme en Belgique dans les années trente à l'aune des transfers politiques // Le Corporatisme dans l'Aire Francophone au XX-ème Siècle / Ed. O. Dard. - Bern, 2011.

27. Luyten, D. Un corporatisme belge, réponse à la crise du liberalisme // Les Relèves en Europe d'un Après-Guerre à L'autre: Racines, Réseaux, Projets et Postérités / Eds. O. Dard and E. Descamps. - Brussels, 2005. - P. 201.

28. Gerard, E. Religion, class and language: The Catholic Party in Belgium // Political Catholicism in Europe / Eds. by W. Kaiser and H. Wohnout. - London, 2004. - P. 106.

29. Conway, M. Collaboration in Belgium: Léon Degrelle and the Rexist Movement. - New Haven, CT, 2003. - P. 45.

30. Panitch, L. The development of corporatism in liberal democracies // Comparative Political Studies. - 1977. Vol. 10, no. 1. - P. 629.

31. Lowerstein, $K$. Occupational representation and the idea of an economic parliament // Social Science. - 1937. Oct. - P. 426.

32. Stepan, A. The state and society ...- P. 47.

33. Kim, W.; Gandhi, J. Co-opting workers under dictatorship // The Journal of Politics. - 2010. - Vol. 72, No. 3. P. 648.

34. Chalmers, D.A. Corporatism and comparative politics // New Directions in Comparative Politics / Ed. by H. J. Wiarda. - Boulder, CO, 1991. - P. 63.

35. Misner, $P$. Christian democratic social policy: Precedents for third-way thinking // European Christian Democracy: Historical Legacies and Comparative Perspectives / Eds. by T. Kselman and J. A. Buttigieg. - Notre Dame, IN, 2003. - P. 77.

36. Loewenstein, $K$. Occupational representation and the idea of an economic parliament // Social Science. - 1937. Oct. - P. 423.

37. См.: Chatriot, A. Georges Valois, la représentation professionelle et le syndicalisme // Georges Valois, Itinéraire et Réceptions / Ed. by O. Dard. - Berne, Peter Lang, 2011. - P. 65.

38. Цит. по: Gómez Navarro, J.L. El régimen de Primo de Rivera. - Madrid, 1991. - P. 234.

39. Wohnout, $H$. Middle-class governmental party and secular arm of the Catholic Church: The Christian Socials in Austria // Political Catholicism ...- P. 184.

40. Классификация основывается на степени принятия институтов, связанных с социальным и политическим корпоративизмом на основе конституций и проектов конституционной реформы, независимо от эффективности их институционализации, учитывая, что некоторые режимы по продолжительности были очень 
недолгими. Мы исключили нацистскую диктатуру из этой таблицы, потому что, даже если она имела некоторые корпоратистские структуры, у нас есть сомнения по поводу возможности классификации нацистской диктатуры по данной шкале.

41. Gandhi, J.; Przeworski, A. Authoritarian institutions and the survival of authocrats // Comparative Political Studies. - 2007. - Vol. 40, No. 11. - P. 1282.

42. Weber, M. Economy and Society: An Outline of Interpretive Sociology. - Berkeley, CA, 1968. - P. 1, 298.

43. А «эти палаты являются только компонентами своих режимов ... никакой законодательный орган при авторитарном режиме не имеет ни формальной, ни фактической власти подвергать сомнению исключительную власть правителя или правящей группы». См.: Linz, J.J. Legislatures in organic-statist-authoritarian regimes: The case of Spain // Legislatures in Development: Dynamics of Change in New and Old States / Eds. by J. Smith and L. D. Musolf. - Durham, NC, 1979. - P. 91, 95.

44. Cм.: Gagliardi, A. Il Corporativismo Fascista. - Rome, 2010. - P. 4.

45. De Grand, A.J. The Italian National Association and the Rise of Fascism in Italy. - Lincoln, NE - London, 1978. P. 100.

46. Perfetti, F. La discussion sul corporativismo in Italia // Les expériences corporatives ...-P. 102-115; Gagliardi, A. Il corporativismo fascista.

47. См.: Perfetti, F. Fascismo e Riforma Istituzionali. Florence, 2013.

48. Musiedlak, D. Lo Stato Fascista e la sua Classe Politica, 1922-43. - Bologna, 2003; Adinolfi, G. Political elite and decision-making in Mussolini's Italy // Ruling Elites ... - P. 19-54.

49. Roberts, D.D. The Syndicalist Tradition and Italian Fascism. - Chapel Hill, NC, 1979.

50. Perfetti, $F$. La discussion.

51. Colombo, P. La Monarchia Fascista, 1922-1940. Bologna, 2010. - P. 105.

52. Di Napoli, M. The Italian Chamber of Fasci and Corporazioni: A substitute for parliament in a totalitarian regime // Repräsentation in Föderalismus und Korporativismus / Hrhg. von W. Brauneder and E. Berger. - Frankfurt am Main, 1998. - P. 257.

53. Musiedlak, D. Le corporatisme dans la structure; Dormagen, J.-Y. Logiques du Fascisme: L'État Totalitaire en Italie. - Paris, 2008; Gagliardi, A. Il corporativismo fascista.

54. Field, L.G. The Syndical and Corporative Institutions of Italian Fascism. - New York, NY, 1938; Di Napoli, M. The Italian chamber.

55. Ibid. - P. 261.

56. Musiedlak, D. Le corporatisme dans la structure ...P. 151.

57. Perfecto, M.A. Influências ideológicas no projecto de corporativismo político-social da ditadura de Primo de Rivera (1923-1930) // Penélope. - 1991. - V. 5. - P. 99108; La droite radicale espagnole et la pensée antiliberale française durant le premier tiers du XX siècle // Georges Valois ... - P. 99-108.

58. Gomez Novarro, J.L. El régimen de Primo de Rivera ...P. 86.

59. Ibid. - P. 207.

60. De Lucena, M. A. Evolução do Sistema Corporativo Português. Vol. 1: O Salazarismo. - Lisbon, 1976.

61. Madureira, A. O 28 de Maio: Elementos para a sua Compreensão.- Lisbon, 1978. - P. 243.

62. Salazar, A. de O. Discursos e Notas Políticos. Vol. 1. Coimbra, 1934. - P. 87.

63. Patriarca, F.A QuestãoSocial no Salazarismo, 1933-47. Lisbon, 1995: Martinho, F.P. A Bem da Nação: O Sindicalismo Português entre a Tradição e a Modernidade. - Rio de Janeiro, 2002.

64. Schmitter, P.C. Portugal: Do Autoritarismo à Democracia. Lisbon, 1999; Wiarda, H.J. Corporatism and Development: The Portuguese Experience. - Amherst, MA, 1977.

65. Araujjo, A. A Lei de Salazar. - Lisbon, 2007; Estevão, $N$. A câmara corporativa no Estado Novo: Composição, funcionamento e influência, Doctoral dissertation, Instituto de Ciências Sociais. - Universidade de Lisboa, 2009.

66. Pinto, A.C. The Blue Shirts: Portuguese Fascism in Interwar Europe. - New York, NY, 2000.

67. Castilho, J.M.T. Os Procuradores a` ICâmara Corporativa, 1935-74. - Lisbon, 2010.

68. Estêvão. N.A câmara corporativa. См. также: Cardoso, J.L.; Ferreira, N.E. A icâmara corporativa e as políticas públicas do Estado Novo // Ler História. - 2013. - V. 64. P. 31-54.

69. Castilho, J.M.T. Os Procuradores.

70. Wiarda, H.J. Corporatism and Development ... - P. 101.

71. Payne, S.G. The Franco Regime, 1936-75. - Madison, WI, 1987. - P.. 323.

72. Jerez Mir, M. Executive, single party and ministers in Franco's regime, 1936-45 // Ruling Elites ... - P. 165213.

73. Payne, S.G. Fascism in Spain. - Madison, WI, 2000; Molinero, $C$. "Sindicalisme Nacional": Una anàlise comparativa entre Italia e Espanya // Nou Estat, Nova Política, Nou Ordre Social: Feixisme en una Perspectiva Comparada / Eds. by G. di Febo and C. Molinero. Barcelona, 2005. - P. 45-77.

74. Garcia, F.B. El sindicalismo Vertical: Burocracia, Control Laboral y Representación de Intereses en la España Franquista (1936-51). - Madrid, 2010.

75. Payne, S. G. The Franco regime ... - P. 285.

76. Ibid. - P. 260.

77. Linz, J.J. Organic-statist-authoritarian.

78. Gunther, R. Public Policy in a No-Party State: Spanish Planning and Budgeting in the Twilight of the Franquist Era. - Berkeley, 1980. - P. 36.

79. Gómez Navarro, J.L. Primo de Rivera ... - P. 2.

80. Diaz-Nosty, B. Las Cortes de Franco. - Barcelona, 1972.

81. Morales, A.G. Autoritarismo y Control Parlamentario en las Cortes de Franco. - Murcia, 1977. 
82. Martinez, R.B. Poder de la Burocracia y Cortes Franquistas, 1943-71. - Madrid, 1978.

83. Pasteur, $P$. "Austrofascisme" ou régime autoritaire corporatiste chrétien? // La Périphérie du Fascisme: Le Cas de L'Europe Central entre les Deux Guerres / Eds. by C. Horel, T. Sandu and F. Taubert. - Paris, 2006. P. 111-22; Les Etats Autoritaires en Europe, 1919-45. Paris, 2007. - P. 120.

84. Von Klemperer, K. Ignaz Seipel: Christian Statesman in a Time of Crises. - Princeton, NJ, 1971. - P. 247.

85. Pasteur, P. Les États Autoritaires en Europe, 1919-45 ... - P. 160.

86. Diamant, A. Austrian Catholics and the First Republic: Democracy and the Social Order, 1918-34. - Princeton, NJ, 1960. - P. 269.

87. Wohnout, H. A chancellorial dictatorship with a "corporative" pretext: The Austrian constitution between 1934 and 1938 // The Dollfuss/Schuschnigg Era in Austria: A Reassessment / Eds. by G. Bishof, A. Pelinka and A. Lassner. - New Brunswick, NJ, 2003. - P. 151.

88. Ibid. - P. 156.

89. Linz, J.J. Organic-statist-authoritarian ... - P. 92.

90. Janos, A. East Central Europe in the Modern World. Stanford, CA, 2000.

91. Janos, A. The Politics of Backwardness in Hungary, 18251945. - Princeton, NJ, 1982. - P. 210.

92. Batkay, W.M. Authoritarian Politics in a Transitional State: Istvan Bethlen and the Unified Party in Hungary, 191926. - New York, NY, 1982.

93. Berend, I.T. Decades of Crises: Central and Eastern Europe before World War Two. - Berkeley, CA, 1998; Vonyó, J. Tentative de l'organization totale de la société hongroise sous le gouvernement de Gyula Gömbös // La périphérie du fascisme... - P. 59; Ormos, M. Hungary between the Wars. - New York, 2008. - P. 254-58.

94. Ormos, M. The Horthy era and the fascist epilogue: 19211945 // Hungary: Government and Politics, 1845-2000 / Eds. by M. Ormos and B. K. Kiŕaly. - New York, NY, 2001. P. 216-274; Romsics, I. Istv́an Bethlen: A Great Conservative Statesman of Hungary. - New York, NY, 1995. - P. 335.

95. Janos, A. Politics of backwardness ... - P. 290.

96. Polonsky, A. Politics of Independent Poland, 1921-39: The Crisis of Constitutional Government. - Oxford, 1972. - P. vii; Levitsky, S.; Way, L.A. Competitive Authoritarianism: Hybrid Regimes after the Cold War. New York, NY, 2010.

97. Преобладание римского католицизма в Польше не привело к созданию сильных католических партий, и хотя «подробная модель корпоратистской системы, которая предполагала установление новой вертикальной системы власти, во главе которой была бы корпоративистская национальная палата» была частью малой программы Христианско-демократической партии, это не повлияло на институциональную реформу Пилсудского. См.: Kuk, L. A powerful Catholic Church, unstable state and authoritarian political regime: The Christian Democratic Party in Poland // Political Catholicism ... - P. 157.
98. Wynot Jr., E.D. Polish Politics in Transition: The Camp of National Unity and the Struggle for Power, 1935-39. - New York, NY, 1974. - P. 24.

99. Общий электорат мог направить делегата в эти избирательные комиссии только с 500 нотариально заверенными подписями, что было совершенно бесполезной процедурой. См. Polonsky, A. Independent Poland ... - P. 397; Wynot Jr., E.D. Polish politics in transition ... - P. 26.

100. Polonsky, A. Independent Poland ... - P. 430.

101. Tiu, I. The Legionary Movement after Corneliu Codrianu. - New York, NY, 2009.

102. Rothschild, J. East Central Europe between the Two World Wars. - Seattle, WA, and London, 1974. - P. 311.

103. Deletant, D. Hitler's Forgotten Ally: Ion Antunescu and his Regime, Romania, 1940-44. - London, 2006.

104. Hoensch, J.K. Catholics, the State and the European Radical Right, 1919-45. - New York, NY, 1987. - P. 174.

105. Ward, J.M. Priest, Politician, Collaborator: Jozef Tiso and the Making of Fascist Slovakia. - Ithaca, NY, and London, 2013. - P. 119.

106. Nedelsky, $N$. The wartime Slovak state: A case study on the relationship between ethnic nationalism and authoritarian patterns of governance // Nations and Nationalisms. - 2001. - Vol. 7, No. 2. - P. 221.

107. Soubigou, A. Le "clerico-fascisme" slovaque fut-il une religion politique? // Vers un Profil Convergent des Fascismes? 'Nouveaux Consensus' et Religion Politique en Europe Central / Ed. by T. Sandu. - Paris, 2010. P. 79.

108. Hoensch, J.K. Catholics ... - P. 180; Poli, D.; Salmi, S. Lo Stato corporativo: Una comparazione fra i casi italiano, portoghese e slovacco // Progetti Corporativi tra le Due Guerre Mondiali / Ed. by M. Pasetti. - Rome, 2006. - P. 165-186.

109. Soubogou, A. Clerico-fascisme ...- P. 76. The six corporations created by the constitution were called estates. Cм.: Lettrich, J. History of Modern Slovakia. New York, NY, 1955. -P. 147-148.

110. Ward, J.M. Priest ... - P. 207.

111. Jelinek, $Y$. The Parish Republic: Hlinka's Slovak People's Party. - New York, NY, 1976. - P. 47-51; Poli, D.; Salmi, S. Lo Stato corporativo ... - P. 173.

112. Ward, J.M. Priest ...-211-217.

113. Crampton, R.J. A Concise History of Bulgaria. Cambridge, 2005. - P. 159.

114. Ibid. - P. 162.

115. Kofas, J. Authoritarianism in Greece: The Metaxas Regime. - New York, NY, 1983. - P. 65.

116 Kallis, A. Neither fascist nor authoritarian: The 4th of August regime in Greece (1936-41) and the dynamics of fascistisation in 1930s Europe // East Central Europe. 2010. - Vol. 37. - P. 303-330.

117. Sarandis, $C$. The ideology and character of the Metaxas regime // Aspects of Greece: The Metaxas Dictatorship / Eds. by R. Highan and T. Veremis. - Athens, 1993. P. 156; Papacosma, S.V. Ioannis Metaxas and the "Fourth of August" dictatorship // Balkan Strongman: Dictators 
and Authoritarian Rulers of South-East Europe / Ed. by F. Bernd. - London, 2006. - P. 187.

118. Eidintas, A. The presidential republic // Lithuania in European politics: The Years of the First Republic, 191840 / Eds. by A. Eidintas, V. Zalys and A. E. Senn. Vilnius, 1997. - P. 111-137.

119. Ibid. - P. 121. См. также: Sabaliunas, L. Lithuania in Crisis: Nationalism to Communism, 1934-1940. Bloomington, IN, 1972. - P. 42.

120. Von Rauch, G. The Baltic States: The Years of Independence, 1917-40. - New York, NY, 1995. - P. 164.

121. Kasekamp, A. The Radical Right in Interwar Estonia.London, 2007. - P. 121.

122. Plakans, A. The Latvians: A Short History. - Stanford, CA, 1995.

123. Von Rauch, G. The Baltic states; Pasteur, P. Les États Autoritaires ...- P. 166.

124. Linz, J.J. Totalitarian and Authoritarian Regimes ...P. 214.

125. Stepan, A. State and Society; Weyland, K. The diffusion ... - P. 1167.
126. Albertus, M.; Menaldo, $V$. Dictators as founding fathers? The role of constitutions under autocracy ... - P. 5, available at ssrn.com/abstract $=1794281$. См. также: Thornhill, C. A Sociology of Constitutions. Constitutions and State Legitimacy in Historical-Sociological Perspective ... - Cambridge, 2011. - P. 310-326.

127. Svolik, $M . W$. The Politics of Authoritarian Rule. - New York, NY, 2012.

128. Brooker, P. Twentieth-Century Dictatorships: The Ideological One-Party States. - New York, NY, 1995. P. 9-10.

129. Ezrow, N.; Frantz, E. Dictators and Dictatorships: Understanding Authoritarian Regimes and their Leaders. London, 2011. - P. 7.

130. Pinto, A.C. Ruling Elites.

131. См.: Rethinking the Nature of Fascism / Ed. by A.C. Pinto. - London, 2011 и The Nature of Fascism Revisited / Ed. by A.C. Pinto. - New York, 2012. 